\title{
Fraxinus xanthoxyloides leaves reduced the level of inflammatory mediators during in vitro and in vivo studies
}

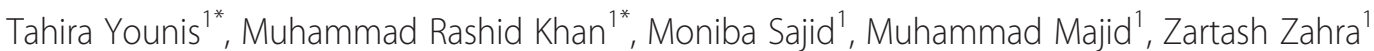
and Naseer Ali Shah ${ }^{2}$

\begin{abstract}
Background: Different parts of Fraxinus xanthoxyloides Wall. (Oleaceae) are used traditionally in the treatment of internal wounds, bone fracture, pain, jaundice, malaria and in pneumonia. These ailments involve protective and essential mechanisms of the organism in response to infection, injury and trauma. However, prolonged inflammation may lead to inflammatory disorders. The present investigation was carried to evaluate the crude methanol extract of F. xanthoxyloides leaves and its fractions for their anti-inflammatory and analgesic effects.
\end{abstract}

Methods: Methanol extract of F. xanthoxyloides leaves was fractionated through liquid-liquid partition on escalating polarity of solvents. Acetic acid and thermal responses were used to evaluate the analgesic effects of extract/fractions in rat. Anti-inflammatory effects were monitored through in vitro; TNF-a activated NFkB in 293/NFkB-Luc HEK cells and LPS-activated nitric oxide (NO) assay in RAW 264.7 cells. For in vivo studies carrageenan induced paw edema model was used in rat. Both in vitro and in vivo studies have indicated that chloroform fraction exhibited superior anti-inflammatory effects to other extract/fractions and therefore, was used in air pouch model in rat to estimate the inhibition in leukocyte migration and synthesis of inflammatory mediators. In addition, phytochemical investigation of crude extract was carried out by GC-MS analysis.

Results: GC-MS studies of crude extract revealed the presence of various classes of which terpenoids (26.61 \%), lactam (16.47\%), esters (15.81\%), phenols (8.37\%), and steroid (6.91\%) constituted the major categories. Among the extracts chloroform fraction $(200 \mathrm{mg} / \mathrm{kg}$ bw) significantly $(P<0.001)$ increased the percent latency time $(76.13 \pm 4.49 \%)$ in hot plate test after $120 \mathrm{~min}$ and decreased $(P<0.001)$ the count of writhes $(77.23 \pm 5.64 \%)$ as compared to other extracts. The in vitro studies indicated that chloroform fraction at $15 \mu \mathrm{g} / \mathrm{ml}$ more effectively inhibited the TNF-a induced synthesis of NFkB $\left(85.0 \pm 8.12 \%, I C_{50}=5.98 \mu \mathrm{g} / \mathrm{ml}\right)$ and LPS-instigated nitric oxide $\left(78.23 \pm 2.39 \%, I C_{50}=6.59 \mu \mathrm{g} / \mathrm{ml}\right)$ synthesis. Although all the extract/fractions showed a dose dependent increase in inhibition of edema formation however, chloroform fraction ( $\left.4^{\text {th }} \mathrm{h}=77.64 \pm 3.04 \%\right)$ at $200 \mathrm{mg} / \mathrm{kg}$ bw exhibited relatively higher $(P<0.001)$ anti-inflammatory activity in carrageenan-induced paw edema in rat. Moreover, chloroform fraction had the ability to decrease $(P<0.001)$ the influx of leukocytes and the concentration of inflammatory mediators; TNF-a, NO, IL-6 and $P G E_{2}$ in air pouch exudate.

Conclusion: The study demonstrates the therapeutic potential of $F$. xanthoxyloides leaves against the inflammatory disorders suggesting the presence of active constituents in chloroform fraction.

Keywords: Anti-inflammatory, Analgesic, Fraxinus xanthoxyloides, NFkB, Nitric oxide, TNF-a

\footnotetext{
*Correspondence: tahirayounis@gmail.com; mrkhanqau@yahoo.com

'Department of Biochemistry, Faculty of Biological Sciences, Quaid-i-Azam

University, Islamabad 45320, Pakistan

Full list of author information is available at the end of the article
} 


\section{Background}

Inflammation usually occurs nearly in all diseases and is considered to be an important causative agent for mortality and morbidity. Inflammation usually involves several metabolic and cellular events coordinated by mediators like cytokines, interleukins, prostaglandins and thromboxanes. A number of disorders such as rheumatoid arthritis, atherosclerosis and asthma have high prevalence worldwide. A number of studies have demonstrated that inflammation is key player that incite or sustain these disorders [1]. There is an up-regulation of tumor necrosis factor (TNF), interferon (INF) $-\gamma$ and interleukin (IL)-1, IL-6, IL12 , IL-18 in early phase of inflammation, which stimulate recruitment of additional neutrophils and macrophages that are associated with the enhanced synthesis of inflammatory mediators such as nitric oxide (NO) and prostaglandin $\left(\mathrm{PGE}_{2}\right)$ [2]. Additionally inflammatory responses augment the leukocytes, macrophages and mast cells to undergo various cellular changes of which the most important are the phagocytic uptake, mast cell degranulation [3] and generation of reactive oxygen species (ROS) [4-6]. These events ultimately incite or endure inflammatory responses together with induction of lipid peroxidation of membranous system and release of damaging macromolecules $[4,6]$. Enhanced production of ROS up-regulate the synthesis of nuclear factor kappa B (NFkB) which in association with other mediators increase the generation of enzymes such as cyclooxygenase (COX)-2 and inducible nitric oxide synthase (iNOS). It is suggested that NFkB also regulate the anti-apoptotic responses [4]. As an antagonist to pathophysiological response of living tissues an increase has been recorded in release of interleukins (IL-4, IL-10, IL-13) and INF- $\alpha$ which together act as anti-inflammatory agents [7]. Finally extravasation of fluids and infiltration of leukocytes at the inflammatory area promote the edema formation [8]. Prolong sustainability of inflammation might result in many inflammatory disorders [9].

These inflammatory responses usually culminate in swelling, warmth, redness, pain and dysfunction. Such type of harmful stimuli are sensitized by specific type of neurons called as nociceptors which are embedded in the epithelium of skin, blood vessels, joints and many internal vital organs. These neurons may be mylenated or not and are activated by heat, cold or an injury and transmit these signals to the central nervous system. Increased secretion of cytokines either from leukocytes and/or central nervous system stimulates the peripheral nociceptors [10].

In spite of the recorded adverse effects of non-steroidal anti-inflammatory drugs (NSAIDs) are the clinicians' first choice throughout the world to relieve pain and inflammation $[11,12]$. Mechanistically they are known to relieve pain and inflammation by decreasing the levels of prostaglandins
(PGs) like PGE2 and PGI2 and inhibiting the cyclooxygenase (COX) enzymes $[13,14]$. Use of PGE2 in inflammation provides moderate level of protection to the gastrointestinal (GI) mucosa by increasing the release of mucus and bicarbonates. However, continuous use of such therapeutics might result in ulceration of lumen and bleeding of intestinal mucosa which collectively known as NSAIDs induced enteropathy. The major factor which contributes to the toxicity of GI is the inhibition of COX but there is also the contribution of other factors like endoplasmic reticulum stress and inflammation $[15,16]$. These may be the effects triggered directly by NSAIDs or appear as downstream effects of COX inhibition. To minimize the adverse effects of NSAIDs, SC-560 as COX-1 selective inhibitor and celecoxib as selective inhibitor of COX2 were developed with the assurance that they will cause less GI toxicity than nonselective NSAIDs [17]. But still these agents employ stomach acidity, bleeding, ulceration $[18,19]$ and hepatotoxicity (elevated levels of serum alanine aminotransferase and aspartate aminotransferase), renal toxicity (increased creatinine level, peripheral edema and hypertension) and cardiovascular toxicity (angina, myocardial infarction, venous blockage, stroke) have been recorded in patients with use of relatively high doses of these compounds [20-22]. NSAIDs are also known to cause periodic colonic ulcers. The use of other NSAIDs like nicorandil is associated with anal and oral ulceration and many patients develop anaemia, diarrhoea or weight loss. However, the mechanism is yet to be established [23].

The main risk factors in ulcers related to the drugs are dependent on the dose and choice of NSAIDs and coprescription of warfarin or corticosteroids. The risk of complications in the ulcer increases with increase in dose. Several meta-analyses have recommended a hierarchy of risk from a low level with low dose of ibuprofen, through the transitional level with diclofenac and to a high level with indomethacin, naproxen, piroxicam, ketoprofen [24]. NSAIDs injure the upper and lower gut and mucosa by depleting the COX-1 derived prostaglandins [25].

On account of low cost and less side effects plant based medicines are preferred worldwide as an alternative of NSAIDs because of the active anti-inflammatory phytoconstituents. There is an increasing trend in the use of plant based medicines and nearly $80 \%$ of the world population prefers these drugs [26]. Nowadays drug discovery from the plants is based upon the bioactive guided fractionation and isolation which has resulted in development of many important drugs [26]. The first drug from plant source which was introduced in the market in 1826 was morphine and the first semi-synthetic pure drug was aspirin which was introduced in 1899 by Bayer is based upon a natural product salicin isolated from Salix alba. After that there was isolation of many other plant based drugs like digitoxin, pilocarpine, cocaine, quinine, codeine 
some of which are still in use [27]. Plant derived drugs which have been introduced in the market during the last few decades include Artemisinin from Artemisia annua to fight with multidrug resistant malaria, Paclitaxel isolated from Taxus brevifolia for ovarian, breast and lung cancer, Silymarin from Silybum marianum used for the treatment of liver diseases [28]. A semisynthetic compound Apomorphine which is used for the treatment of Parkinson's disease is a derivative of morphine (Papaver somniferum). Tiotropium derived from atropine (Atropa belladonna) is used in chronic obstructive pulmonary disease. From Cannabis sativa, Dronabinol and Cannabidiol and Capsaicin from Capsicum annuum were obtained and are used as pain relievers. From Catharanthus roseus, Vincristine and vinblastine were extracted which are highly treasured anticancer drugs. Galantamine acquired from Galanthus nivalis is a natural alkaloid for Alzhemer's are further prominent examples of secondary plant metabolites [29]. Other very important plant based antiinflammatory compounds i.e. curcumin, colchicine, resveratrol, epigallocatechin-3-gallate (EGCG) and quercetin are in clinical trial [30].

Fraxinus xanthoxyloides (Wall. ex G.Don) DC. (Family Oleaceae) commonly known as Afghan ash is found in Northern areas of Pakistan, Afghanistan, India, Morocco and in Algeria. In northern areas of Pakistan its leaves and root bark has been used to treat jaundice, malaria and pneumonia. Decoction of stem bark $(2-3 \mathrm{~g})$ is given to reduce pain during labor [31]. Its wood is reported to be used in bone fracture [32]. Decoction of bark is used to expel pre-mature infant after death [33] and to cure internal wounds/injuries [34]. Decoction of stem/twigs is also used in wounds and bone fractures in cattle [35]. Remarkable anti-nociceptive and anti-inflammatory activities of the methanol extract at 200 and $400 \mathrm{mg} / \mathrm{kg}$ doses of Fraxinus floribunda leaves have been reported [36]. Administration of $10 \mathrm{mg} / \mathrm{kg}$ of methanol extract of the aerial parts of $F$. micrantha produced significant anti-inflammatory effects against carrageenan-induced acute inflammation in mice [37]. Xanthoxyloidin, a new biscoumarin together with esculetin, 5,7- dihydroxycoumarin and 6,8-dihydroxy-7-methoxycoumarin were isolated from the methanol extract of the whole plant of $F$. xanthoxyloides [38]. Intraperitoneal administration of stem bark extract of $F$. ornus displayed anti-inflammatory activity in both zymosan- and carrageenan-induced paw edema in mice [39]. Anti-nociceptive and anti-inflammatory activities of the methanol extract at 200 and $400 \mathrm{mg} / \mathrm{kg}$ doses of F. floribunda leaves have been reported [40]. There is no earlier report about the anti-inflammatory and analgesic activity of any extract or fractions of this plant. In this study we examined the anti-inflammatory and analgesic effect of the crude methanol extract of $F$. xanthxyloides leaves and its fractions. In this investigation we have evaluated the methanol extract of $F$. xanthxyloides stem bark and its derived fractions for anti-nociceptive and anti-inflammatory activities. GC-MS analysis of the crude extract was also performed.

\section{Methods \\ Plant collection}

The plant of $F$. xanthoxyloides was collected and identified by Dr. Rizwana Aleem Qureshi, Professor at the Department of Plant Sciences, Quaid-i-Azam University, Islamabad. Leaves of the F. xanthxyloides were collected in October, 2013 from the campus of Quaid-i-Azam University Islamabad, and a voucher specimen (45679) was submitted to Herbarium of Pakistan, Quaid-i-Azam University Islamabad, Pakistan.

\section{Extract preparation}

The leaves obtained were dried under shade at $25 \pm 2.0{ }^{\circ} \mathrm{C}$. Powder of $F$. xanthoxyloides leaves $(1.5 \mathrm{~kg})$ was extracted with $95 \%$ methanol $(4.5 \mathrm{~L})$ twice for $72 \mathrm{~h}$ at $25 \pm 2.0{ }^{\circ} \mathrm{C}$. The filtrate obtained was mixed and dried under vacuum in a rotatory evaporator at $40{ }^{\circ} \mathrm{C}$ to get $150 \mathrm{~g}$ of the crude methanol extract (FXM). A portion (100 g) of FXM was suspended in $400 \mathrm{ml}$ of distilled water and fractionated by liquid-liquid partition by the addition of $400 \mathrm{ml}$ of each solvent twice in order of $n$-hexane, chloroform, ethyl acetate and $n$-butanol. The organic layers were separated and dried under vacuum in a rotatory evaporator at $40{ }^{\circ} \mathrm{C}$. Before drying the layers of the respective solvent were mixed together. The yield obtained for each solvent was; $18.45 \mathrm{~g}$ for $n$-hexane (FXH), $12.0 \mathrm{~g}$ for chloroform (FXC), $9.01 \mathrm{~g}$ for ethyl acetate (FXE), $12.83 \mathrm{~g}$ for $n$-butanol (FXB) and the soluble aqueous fraction (FXA) was 43.33 g. Crude extract and fractions were stored at $4{ }^{\circ} \mathrm{C}$ for various assays.

\section{Animals}

We have used the Sprague-Dawley rats (150-200 g) of either sex for various studies. The animals were maintained in the primate facility at Faculty of Biological Sciences, Quaid-i-Azam University Islamabad, Pakistan at standard condition of temperature $\left(25 \pm 1{ }^{\circ} \mathrm{C}\right)$ and $12 / 12 \mathrm{~h}$ light/ dark cycle. The animals have free access to feed and water ad libitum. The use of animals for experimentation was conducted according to the guidelines of National Institute of Health (NIH), Islamabad, Pakistan. The protocol followed in this study was approved (Bch\#0263) by the Ethical committee of Quaid-i-Azam University Islamabad, Pakistan.

\section{Acute toxicity studies}

To determine the acute toxicity of the extract/fractions, the guidelines 425 advocated by the Organization for Economic Cooperation and Development (OECD) were followed [41]. For this purpose Sprague-Dawley rats $(n=6)$ including 
males and females were orally administered at various doses of the extract/fractions (50, 250, 500, 1000, 2000, $3000 \mathrm{mg} / \mathrm{kg}$ ) par oral (p.o.), whereas saline $(10 \mathrm{ml} / \mathrm{kg})$ was administered to the control rats. The animals were examined once daily for 14 days for mortality, behavioral pattern (lethargy, sleep, salivation), changes in physical appearance, injury, pain, and signs of illness.

\section{Pharmacological activities \\ Analgesic studies \\ Acetic acid induced writhing test}

To determine the analgesic activity of the extract/fractions obtained from the leaves of $F$. xanthoxyloides, a method previously reported by Khan et al. [42] was employed. In this model diclofenac sodium and aspirin were used at a concentration of $10 \mathrm{mg} / \mathrm{kg}$, par oral (p.o) as standard drugs. Total number of writhing movements following p.o. administration of acetic acid solution $(10 \mathrm{ml} / \mathrm{kg}, 1 \%)$ was recorded over a period of $10 \mathrm{~min}$, starting $5 \mathrm{~min}$ after acetic acid injection. Rats (6 in each group) were treated with FXM and its derived fractions; FXH, FXC, FXE, FXB and FXA (100 and $200 \mathrm{mg} / \mathrm{kg}$ ), vehicle (saline), standard drugs (diclofenac sodium and aspirin $10 \mathrm{mg} / \mathrm{kg}$ ), $30 \mathrm{~min}$ before acetic acid injection. The numbers of writhing movements (Constriction of abdominal muscles along with the stretching of hind limbs) were counted in both untreated and treatment groups and percentage inhibition in abdominal writhing was calculated as follow.

$$
\% \text { inhibition of abdominal writhing }=\left[\frac{(\mathrm{Wc}-\mathrm{Wt})}{(\mathrm{Wc})} \times 100\right]
$$

$\mathrm{W}=$ No. of writhing, $\mathrm{c}=$ Control, and $\mathrm{t}=$ Test.

\section{Hot plate test}

Sprague-Dawley rats of either sex weighing 150-200 g were used in this experiment to perform the analgesic test [43]. Before the animals were used to determine the analgesic effect of various extract/fractions; animals were pre-tested on hot plate analgesimeter (Havard apparatus Ltd., UK) which was maintained at $55 \pm 0.1^{\circ} \mathrm{C}$ to exclude the rats exhibiting $>15 \mathrm{~s}$ of latency period. Animals were divided randomly into 15 groups with six rats in each group. In this study the animals of negative control were injected with normal saline $2 \mathrm{ml}$, i.p. whereas the animals of the positive groups received $10 \mathrm{mg} / \mathrm{kg}$, p.o. of the diclofenac sodium and morphine respectively. Animals of the other groups were administered with doses of $100 \mathrm{mg} / \mathrm{kg}$, p.o. and $200 \mathrm{mg} / \mathrm{kg}$, p.o. of the FXM and its derived fractions; FXH, FXC, FXE, FXB and FXA. Latency period (time for which rat remains on the hot plate without licking or flicking of hind limb or jumping) in second was recorded for each animal of the group at 0 and after 30, 60 and $120 \mathrm{~min}$ of dose administration.
In order to prevent the tissue damage the cut off time of $30 \mathrm{~s}$ was set for all animals. Percent analgesia was calculated using the following formula.

$$
\% \text { Analgesia }=\left[\frac{(\text { Test latency }- \text { control latency })}{(\text { Cut off time }- \text { control latency })} \times 100\right]
$$

\section{Anti-inflammatory activity In vitro anti-inflammatory activities Inhibition of TNF- $a$ activated NFkB assay}

Inhibition of TNF- $\alpha$ activated nuclear factor kappa-B (NFkB) assay was performed on 293/NFkB-Luc HEK cells purchased from Panomics (Freemont, CA, USA). Cells were seeded at a density of $2 \times 10^{4}$ cells per $200 \mu \mathrm{l}$ in sterile white-walled 96-well plate having Dulbecco's Modified Eagle Medium supplemented with $10 \%$ fetal bovine serum and antibiotic. After incubation for $48 \mathrm{~h}$ in $5 \%$ $\mathrm{CO}_{2}$ at $37{ }^{\circ} \mathrm{C}$, DMSO (10\%) was added without or with $0.5,10,15,20,25,30,40 \mu \mathrm{g} / \mathrm{ml}$ of the extract/fraction and $10 \mathrm{ng} / \mathrm{ml}$ of TNF- $\alpha$ at a final concentration in the fresh medium. The cells after incubation for $6 \mathrm{~h}$ at $37{ }^{\circ} \mathrm{C}$ were washed with PBS. Cells obtained were lysed in $50 \mu \mathrm{l}$ of $1 \mathrm{X}$ reporter lysis buffer with one freeze/thaw cycle $\left(-80{ }^{\circ} \mathrm{C} /\right.$ $37^{\circ} \mathrm{C}$ ). By using the Luciferase Assay System from Promega (Madison, WI, USA) the inhibition of NFkB was recorded in a luminometer according to the manufacturer's instructions. In this assay cells not instigated with TNF- $\alpha$ were used as negative control whereas the cells not treated with DMSO and TNF- $\alpha$ were considered as positive control. The experiment was performed in three replications. After determination of percentage inhibition of NFkB the $\mathrm{IC}_{50}$ values were computed [44]. The data were then plotted graphically as dose response curve after changing the concentration of extract/fractions to the log scale.

\section{Inhibition of LPS-induced nitric oxide synthesis (nitrite assay)}

To examine the anti-inflammatory effects of the crude methanol extract and fractions from leaves of F. xanthoxyloides, LPS-stimulated macrophage model was used [45]. RAW 264.7 cells (ATCC-TIB-71) were seeded at a density of $10 \times 10^{4}$ cells per well in 96-well plate on $10 \%$ FBS containing DMEM and incubated for $24 \mathrm{~h}$ at $37{ }^{\circ} \mathrm{C}$. Extract/ fractions in $10 \%$ DMSO solution at a final concentration of $0.5,10,15,20,25,30,40 \mu \mathrm{g} / \mathrm{ml}$ in $1 \%$ FBS-containing phenol red free DMEM were added and incubated further for $15 \mathrm{~min}$ at $37^{\circ} \mathrm{C}$. Cells were stimulated by the addition of $1 \mu \mathrm{g} / \mathrm{ml}$ of LPS and incubated further for $20 \mathrm{~h}$ at $37{ }^{\circ} \mathrm{C}$. Cells not stimulated with LPS were considered as a negative control whereas cells treated with LPS and DMSO used as positive control. To determine the anti-inflammatory potential of extract/fractions, an aliquot of $100 \mu \mathrm{l}$ of the incubation media was transferred to 96-well plate and allowed 
to react with Griess reagent $(90 \mu \mathrm{l}$ of $1 \%$ sulfanilamide in $5 \%$ phosphoric acid, and $90 \mu \mathrm{l}$ of $N$-(1-naphthyl) ethylenediamine). Absorbance of the reaction mixture was recorded at $540 \mathrm{~nm}$. The experiment was performed in three replications. After determination of percentage inhibition of nitric oxide $\mathrm{IC}_{50}$ values were computed. The data were then plotted graphically as dose response curve after changing the concentration of extract/fractions to the log scale.

\section{Cytotoxicity studies for dose response}

Characterization of extract/fractions for cytotoxicity was demonstrated according to You et al. [46] by the sulforhodamine B assay. Briefly, $190 \mu \mathrm{l}$ of cells with a density of $5 \times 10^{4}$ cells $/ \mathrm{ml}$ of both 293/NFkB-Luc HEK cells and RAW 264.7 cells (ATCC-TIB-71) were seeded in 96-well plate having $10 \mu \mathrm{l}$ of the test sample (final concentration of $20 \mu \mathrm{g} / \mathrm{ml})$ in DMSO (10 \%) and PBS, and incubated for $72 \mathrm{~h}$ at $37{ }^{\circ} \mathrm{C}$ in $\mathrm{CO}_{2}$ incubator. After incubation $50 \mu \mathrm{l}$ of $20 \%$ TCA was added to terminate the reaction. Cells were washed, dried and stained with $0.4 \%$ of acetic acid for $30 \mathrm{~min}$ at room temperature. Cells were washed four times with acetic acid and dried overnight. Bound dye was solubilized in $200 \mu \mathrm{l}$ of $10 \mathrm{mM}$ of Tris base (pH $=10$ ) on a gyratory shaker for $10 \mathrm{~min}$. Absorbance of each treatment was recorded at $515 \mathrm{~nm}$ through a micro-plate reader. A zero-day control was performed in each case following addition of equal quantity of cells in 16 wells, with subsequent incubation for $30 \mathrm{~min}$ at $37^{\circ} \mathrm{C}$ and was processed as mentioned earlier. Cell survival percentage was calculated for each test sample. The data were presented graphically as dose response curve after changing the concentration of extract/fractions as log scale.

\section{Cytotoxicity studies for timed response}

The dose response curve has indicated that FXC as compared to other extract/fractions had more effectively inhibited the synthesis of NFkB and NO in the respective assays. To establish the time response curve for cytotoxicity the FXC was used at concentration of $2 \times \mathrm{IC}_{50}, 1 \times \mathrm{IC}_{50}$ and $1 /$ $2 \times \mathrm{IC}_{50}$ for $6,12,18,24,30$ and $36 \mathrm{~h}$. The experiment was performed in triplicate. The data obtained was graphically presented as time response curve.

\section{In vivo anti-inflammatory studies \\ Carrageenan induced paw edema}

To assess the anti-inflammatory potential of the test samples carrageenan-induced inflammation model in rat was used [43]. Accordingly, Sprague-Dawley rats (150-200 g) were randomly assigned into 14 groups containing six rats each. At the primate facility of Quaid-i-Azam University Islamabad, rats were maintained at standard laboratory conditions and had free access to the laboratory feed and water ad libitum. Animals of various groups received
$100 \mathrm{mg} / \mathrm{kg}$ and $200 \mathrm{mg} / \mathrm{kg}$, p.o. of FXM and its derived fractions. For this study the standard drug used was diclofenac sodium at $10 \mathrm{mg} / \mathrm{kg}$, p.o. whereas saline $2 \mathrm{ml}$, p.o. was given to negative control animals. After one hour of the extract/fractions or the standard drugs, rats were injected with $1 \%$ of carrageenan into the plantar tissue of the right hind paw. Paw volume was measured plethysgraphically at $0^{\text {th }}, 1^{\text {st }}, 2^{\text {nd }}, 3^{\text {rd }}$ and $4^{\text {th }} \mathrm{h}$ after carrageenan injection and the following formulae for calculating percent inhibition of edema were used;

$$
\mathrm{EV}=\mathrm{PVA}-\mathrm{PVI}
$$

Where, EV = Edema volume, PVI = Paw volume before carrageenan administration (i.e. initial paw volume) and, PVA $=$ Paw volume after carrageenan administration.

$$
\text { Percent inhibition }=\left[\frac{(\mathrm{EVc}-\mathrm{EVt})}{(\mathrm{EVc})} \times 100\right] .
$$

$\mathrm{EVc}=\mathrm{Edema}$ volume of control animals, $\mathrm{EVt}=\mathrm{Edema}$ volume of test sample animals

\section{Subcutaneous air pouch}

To determine the anti-inflammatory activity of FXC in air pouch model, Sprague-Dawley male rats (200-250 g) were divided into five groups having six rats in each. For the development of air pouch on back side of rat $20 \mathrm{ml}$ of sterile air was injected on day 0 , and re-injected 2 and 5 days later with $10 \mathrm{ml}$ of sterile air. On the following day the rats orally received tested drugs $(100 \mathrm{mg} / \mathrm{kg}$ p.o., $200 \mathrm{mg} / \mathrm{kg}$ p.o.), diclofenac sodium (10 mg/kg p.o.) as standard or vehicle ( $2.5 \mathrm{ml}$ saline). Carrageenan solution ( $1 \%$ in saline solution) of $1 \mathrm{ml}$ was injected in the pouch $1 \mathrm{~h}$ after the administration of drugs. Animals were euthanized after $6 \mathrm{~h}$ and the pouch was washed with $3 \mathrm{ml}$ of PBS.

\section{Cell count}

To assess the leukocytes in the exudate, cell pellet was obtained by centrifugation at $500 \times \mathrm{g}\left(4{ }^{\circ} \mathrm{C}\right)$. Cell pellet was suspended in $1000 \mu \mathrm{l}$ of PBS and after staining the leukocytes with hematoxylin and eosin (Sigma-Aldrich, MO, USA) the total cell number and differential cell count was made using a Neubauer hemocytometer. The supernatant was used for estimation of inflammatory mediators.

\section{Inflammatory mediators}

The level of inflammatory mediators TNF- $\alpha$ and IL-6 was determined with commercial ELISA kits from OptEIA rat set while $\mathrm{PGE}_{2}$ was assessed by ELISA kit from Biotrend. The concentration was measured according to manufacturer's instructions. The concentration of NO was estimated with Griess reagent $(90 \mu \mathrm{l}$ of $1 \%$ 
sulfanilamide in $5 \%$ phosphoric acid, and $90 \mu \mathrm{l}$ of $\mathrm{N}$-(1naphthyl) ethylenediamine). Absorbance of the reaction mixture was recorded at $540 \mathrm{~nm}$.

\section{Gas chromatography-mass spectrometry of FXM}

GC-MS analysis was done by using GC-Mass spectrometer system (Model, Thermo GC-Trace ultra-version 5.0, Thermo MS DSQ-II, Thermo Fisher, USA), ZB 35-MS Capillary standard non-polar column $(30 \mathrm{mts}$. X $0.25 \mathrm{~mm}$, $0.25 \mathrm{~m}$ film thickness). Oven temperature programmed from 70 to $260{ }^{\circ} \mathrm{C}$ at $6{ }^{\circ} \mathrm{C} / \mathrm{min}$. The $1 \mu \mathrm{l} / \mathrm{min}$ volume of methanol extract sample was injected into the instrument and detected by splitless injection technique. The compounds were separated using Helium $(1.0 \mathrm{ml} / \mathrm{min})$ as the carrier gas [47]. The constituents present in the analyzed methanol leaf extract of $F$. xanthoxyloides were identified in comparison with their specters of mass with those gathered in a library search (NIST - MS) results and with those reported in the literature (Chemdata.nist.gov/).

\section{Statistical analysis}

All the data obtained was reported as mean $\pm \mathrm{SD}$. One was analysis of variance was used to calculate the variation among various groups by using Statistix 8.1. Significant differences among groups were calculated by Tukey's multiple comparison tests. Statistical significance was set at $P>0.05$. GraphPad Prism 5 was used to determine the $\mathrm{IC}_{50}$ values for in vitro studies.

\section{Results}

Peripheral analgesic effect

Acetic acid induced writhing test

A dose dependent response of the rats towards the count of writhes was exhibited by FXM and its fractions when subjected to the acetic acid induced writhing test (Table 1 ). FXC at $200 \mathrm{mg} / \mathrm{kg}$, p.o. reduced the writhing count up to $77.23 \pm 5.64 \%$ as against the $80.04 \pm 5.25 \%$ and $73.00 \pm$ $4.87 \%$ of diclofenac sodium and aspirin, respectively. The inhibitory effect of diclofenac sodium and aspirin did not differ $(P>0.05)$ from protective effect of FXC $(200 \mathrm{mg} / \mathrm{kg})$, in number of writhes induced with $1 \%$ solution of acetic acid. The percent inhibition in writhes induced with other fractions at $200 \mathrm{mg} / \mathrm{kg}$, p.o. exhibited following order; FXM $>$ FXE $>$ FXB $>$ FXH $>$ FXA.

\section{Central analgesic effect}

\section{Hot plate method (Thermal stimulation)}

We performed the hot plate test, to assess the influence of $F$. xanthoxyloides crude extract (FXM) and its derived fractions on the thermal stimulation as central analgesic effect. Plant extract/fractions were used at 100 and $200 \mathrm{mg} / \mathrm{kg}$ dosages and latency time (seconds) was recorded at $0,30,60$ and $120 \mathrm{~min}$ after the treatment of
Table 1 Effect of FXM and its fractions in acetic acid induced writhing test in rat

\begin{tabular}{|c|c|c|c|}
\hline Groups & Drug (dose), route & $\begin{array}{l}\text { No. of writhing } \\
\text { (Mean } \pm \text { SD) }\end{array}$ & $\%$ Inhibition \\
\hline Saline & 2 ml, i.p. & $71.00 \pm 2.52^{\mathrm{a}}$ & 0 \\
\hline FXM & 100 mg/kg, p.o. & $30.50 \pm 1.87^{9}$ & $57.04 \pm 3.63$ \\
\hline FXM & 200 mg/kg, p.o. & $22.00 \pm 3.41^{\mathrm{h}}$ & $69.01 \pm 4.98$ \\
\hline FXH & 100 mg/kg, p.o. & $63.50 \pm 1.87^{\mathrm{b}}$ & $10.56 \pm 2.63$ \\
\hline FXH & 200 mg/kg, p.o. & $51.00 \pm 2.19^{\mathrm{de}}$ & $28.16 \pm 3.08$ \\
\hline FXC & 100 mg/kg, p.o. & $39.16 \pm 3.48^{f}$ & $44.83 \pm 4.91$ \\
\hline FXC & 200 mg/kg, p.o. & $16.16 \pm 3.62^{i j}$ & $77.23 \pm 5.64$ \\
\hline FXE & 100 mg/kg, p.o. & $59.00 \pm 1.41^{b c}$ & $16.90 \pm 2.02$ \\
\hline FXE & 200 mg/kg, p.o. & $48.00 \pm 2.44^{e}$ & $32.39 \pm 3.14$ \\
\hline FXB & 100 mg/kg, p.o. & $55.66 \pm 1.63^{\mathrm{cd}}$ & $21.59 \pm 2.30$ \\
\hline FXB & 200 mg/kg, p.o. & $52.16 \pm 1.16^{\mathrm{de}}$ & $26.52 \pm 1.64$ \\
\hline FXA & 100 mg/kg, p.o. & $62.00 \pm 1.78^{b}$ & $12.67 \pm 2.51$ \\
\hline FXA & 200 mg/kg, p.o. & $54.33 \pm 1.75^{c d}$ & $23.47 \pm 2.46$ \\
\hline Diclofenac sodium & 10 mg/kg, i.p. & $14.16 \pm 2.60^{j}$ & $80.04 \pm 5.25$ \\
\hline Aspirin & 10 mg/kg, i.p. & $19.16 \pm 2.46^{\mathrm{hi}}$ & $73.00 \pm 4.87$ \\
\hline
\end{tabular}

FXM F. xanthoxyloides methanol extract, FXH F. xanthoxyloides n-hexanefraction, FXC F. xanthoxyloides chloroform fraction, FXE F. xanthoxyloides ethyl acetate fraction, FXB F. xanthoxyloides n-butanol fraction, FXA F. xanthoxyloides residual aqueous fraction. Data values shown represent mean $\pm S D(n=6)$. One-way ANOVA followed by Tukey's HSD multiple comparison tests. Different alphabets in each column indicate difference at $P<0.05$

extract/fractions. Generally all the extract/fractions variably increased the latency time over dosages and time after the treatment (Table 2). Treatment of diclofenac sodium and morphine, $30 \mathrm{~min}$ after the drug treatment, induced $>50 \%$ analgesia by increasing the latency time of licking whilst; $60 \mathrm{~min}$ after the drug treatment, diclofenac sodium, morphine and FXM $(200 \mathrm{mg} / \mathrm{kg})$ exhibited $>50 \%$ analgesia. The response of the rats with FXM and FXC towards the thermal stimulation, 120 min after the administration of extract/fractions was significantly enhanced and maximum percent analgesia was exhibited by FXC $(200 \mathrm{mg} / \mathrm{kg})$ followed by FXM $(200 \mathrm{mg} / \mathrm{kg})$. Percent analgesia exhibited by FXC $(200 \mathrm{mg} / \mathrm{kg})$ was statistically similar $(P>0.001)$ to the percent analgesia induced with diclofenac sodium and morphine, $120 \mathrm{~min}$ after the administration of the extract/fractions. Percent analgesia exhibited by other fractions $(200 \mathrm{mg} / \mathrm{kg}), 120 \mathrm{~min}$ after the administration, was recorded in order of FXE $>$ FXH $>$ FXB > FXA.

\section{In vitro anti-inflammatory activities} Inhibition of TNF-a activated nuclear factor kappa-B (NFkB assay)

The present study demonstrate the inhibitory potential of the crude methanol extract and its fractions of the leaves of F. xanthoxyloides on TNF- $\alpha$ instigated NFkB on 293/NFkB-Luc HEK cells (Fig. 1a). The extract/ 
Table 2 Effect of FXM and its fractions in hot plate test

\begin{tabular}{|c|c|c|c|c|c|}
\hline \multirow[t]{2}{*}{ Treatment } & \multirow[t]{2}{*}{ Dose/route } & \multirow{2}{*}{$\begin{array}{l}\text { Mean latency time } \\
\text { in seconds } \\
0 \text { min }\end{array}$} & \multicolumn{3}{|c|}{ Increase in latency time (seconds) after various dosages (Mean \pm SD)/Percent analgesia } \\
\hline & & & $30 \mathrm{~min}$ & $60 \mathrm{~min}$ & $120 \mathrm{~min}$ \\
\hline \multirow[t]{2}{*}{ Saline } & $2 \mathrm{ml}$, i.p. & $8.83 \pm 0.75$ & $10.33 \pm 0.51$ & $9.83 \pm 0.40$ & $9.50 \pm 0.44$ \\
\hline & & & $7.03 \pm 2.41^{\mathrm{e}}$ & $4.65 \pm 2.87^{h}$ & $3.03 \pm 2.69^{i}$ \\
\hline \multirow[t]{2}{*}{ FXM } & 100 mg/kg, p.o. & $9.33 \pm 0.51$ & $13.00 \pm 0.89$ & $15.50 \pm 0.54$ & $17.00 \pm 0.63$ \\
\hline & & & $17.61 \pm 6.27^{c}$ & $29.80 \pm 3.19^{e}$ & $37.10 \pm 2.44^{c d}$ \\
\hline \multirow[t]{2}{*}{ FXM } & 200 mg/kg, p.o. & $9.66 \pm 1.03$ & $16.50 \pm 0.54$ & $21.33 \pm 1.03$ & $23.66 \pm 1.03$ \\
\hline & & & $33.46 \pm 4.41^{b}$ & $57.35 \pm 4.72^{c}$ & $68.72 \pm 5.71^{b}$ \\
\hline \multirow[t]{2}{*}{ FXH } & 100 mg/kg, p.o. & $9.50 \pm 0.54$ & $10.33 \pm 0.51$ & $12.00 \pm 0.89$ & $13.66 \pm 0.51$ \\
\hline & & & $4.00 \pm 3.59^{\mathrm{de}}$ & $12.10 \pm 5.78^{\text {fgh }}$ & $20.31 \pm 1.77^{f g h}$ \\
\hline \multirow[t]{2}{*}{ FXH } & 200 mg/kg, p.o. & $9.50 \pm 0.54$ & $10.66 \pm 0.51$ & $13.66 \pm 0.51$ & $15.66 \pm 0.51$ \\
\hline & & & $5.63 \pm 3.56^{\text {de }}$ & $20.31 \pm 1.77^{\text {ef }}$ & $30.00 \pm 4.08^{\mathrm{def}}$ \\
\hline \multirow[t]{2}{*}{ FXC } & 100 mg/kg, p.o. & $9.16 \pm 0.75$ & $12.33 \pm 0.51$ & $15.00 \pm 0.89$ & $18.00 \pm 0.89$ \\
\hline & & & $15.13 \pm 3.23^{\mathrm{cd}}$ & $27.99 \pm 3.46^{\mathrm{e}}$ & $42.33 \pm 4.83^{c}$ \\
\hline \multirow[t]{2}{*}{ FXC } & 200 mg/kg, p.o. & $9.00 \pm 0.63$ & $15.66 \pm 0.51$ & $18.66 \pm 0.51$ & $25.00 \pm 0.89$ \\
\hline & & & $31.69 \pm 3.14^{b}$ & $45.99 \pm 3.89^{d}$ & $76.13 \pm 4.49^{\mathrm{ab}}$ \\
\hline \multirow[t]{2}{*}{ FXE } & 100 mg/kg, p.o. & $9.66 \pm 0.51$ & $12.00 \pm 0.89$ & $12.33 \pm 0.51$ & $13.33 \pm 0.51$ \\
\hline & & & $11.46 \pm 4.01^{\text {cde }}$ & $13.05 \pm 3.72^{\text {fgh }}$ & $18.01 \pm 2.37^{f g h}$ \\
\hline \multirow[t]{2}{*}{ FXE } & 200 mg/kg, p.o. & $9.66 \pm 0.81$ & $12.33 \pm 0.51$ & $14.66 \pm 0.51$ & $16.66 \pm 0.89$ \\
\hline & & & $13.02 \pm 3.81^{c d}$ & $24.54 \pm 2.44^{\mathrm{e}}$ & $34.39 \pm 3.24^{\text {cde }}$ \\
\hline \multirow[t]{2}{*}{ FXB } & 100 mg/kg, p.o. & $9.33 \pm 1.03$ & $10.33 \pm 0.72$ & $12.33 \pm 0.51$ & $14.00 \pm 0.89$ \\
\hline & & & $4.60 \pm 2.11 d^{e}$ & $14.42 \pm 2.43^{\mathrm{fg}}$ & $22.53 \pm 3.36^{\mathrm{fgh}}$ \\
\hline \multirow[t]{2}{*}{ FXB } & 200 mg/kg, p.o. & $9.83 \pm 0.75$ & $11.16 \pm 0.89$ & $12.83 \pm 0.51$ & $15.00 \pm 0.89$ \\
\hline & & & $5.63 \pm 3.42^{\text {de }}$ & $10.59 \pm 6.40^{g h}$ & $25.53 \pm 5.14^{\mathrm{efg}}$ \\
\hline \multirow[t]{2}{*}{ FXA } & 100 mg/kg, p.o. & $9.50 \pm 0.54$ & $9.66 \pm 0.51$ & $11.66 \pm 0.51$ & $12.33 \pm 0.51$ \\
\hline & & & $3.75 \pm 0.65^{c}$ & $10.47 \pm 4.55^{g h}$ & $13.77 \pm 3.41^{\mathrm{h}}$ \\
\hline \multirow[t]{2}{*}{ FXA } & 200 mg/kg, p.o. & $9.00 \pm 0.89$ & $10.33 \pm 0.51$ & $12.00 \pm 0.89$ & $13.66 \pm 1.03$ \\
\hline & & & $6.13 \pm 4.21^{\text {cde }}$ & $14.30 \pm 1.61^{\mathrm{fg}}$ & $22.25 \pm 2.68^{\text {fgh }}$ \\
\hline \multirow[t]{2}{*}{ Diclofenac sodium } & 10 mg/kg, i.p. & $9.83 \pm 0.75$ & $21.66 \pm 0.51$ & $26.66 \pm 1.51$ & $26.66 \pm 1.62$ \\
\hline & & & $58.69 \pm 1.45^{\mathrm{a}}$ & $83.51 \pm 4.21^{\mathrm{a}}$ & $83.39 \pm 5.07^{\mathrm{a}}$ \\
\hline \multirow[t]{2}{*}{ Morphine } & 10 mg/kg, i.p. & $9.33 \pm 0.51$ & $20.16 \pm 0.75$ & $23.66 \pm 0.81$ & $23.00 \pm 0.89$ \\
\hline & & & $52.34 \pm 4.59^{a}$ & $69.36 \pm 3.84^{b}$ & $66.03 \pm 5.13^{b}$ \\
\hline
\end{tabular}

FXM F. xanthoxyloides methanol extract, FXH F. xanthoxyloides n-hexanefraction, FXC F. xanthoxyloides chloroform fraction, FXE F. xanthoxyloides ethyl acetate fraction, FXB F. xanthoxyloides n-butanol fraction, FXA F. xanthoxyloides residual aqueous fraction. Data values shown represent mean \pm SD ( $n=6$ ). One-way ANOVA followed by Tukey's HSD multiple comparison tests. Percentage analgesia is shown in brackets. Different alphabets in each column indicate difference at $P<0.05$

fractions variably inhibited the NFkB except the FXH where up-regulation of NFkB activity was recorded at all concentrations. The most potent inhibitor of NFkB activity was the FXC and it has effectively inhibited the activity $(85.0 \pm 8.12 \%)$ at $15 \mu \mathrm{g} / \mathrm{ml}$ concentration. The inhibitory effect at the same dose followed by other extract/fractions was FXM $(34.46 \pm 1.86 \%)>$ FXA $(18.8 \pm$ $5.61 \%)>$ FXB $(13.7 \pm 0.86 \%)>$ FXE $(5.6 \pm 0.70 \%)$. FXC had demonstrated $\mathrm{IC}_{50}$ value of $5.98 \mu \mathrm{g} / \mathrm{ml}$. Survival percentage recorded by sulforhodamine $B$ assay indicated that FXA only induced the cytotoxicity at all the doses. All the other extract/fractions used in this experiment did not induce cytotoxicity up till $20 \mu \mathrm{g} / \mathrm{ml}$ concentration in the medium (Fig. 2a).

Inhibition of LPS-induced NO production (nitrite assay) In this experiment nitric oxide (NO) production was induced with the application of LPS during in vitro conditions and estimation of nitrite; the major oxidized metabolite of nitric oxide was recorded (Fig. 1b). Application of FXC was the most effective and inhibited the production of $\mathrm{NO}$ at $15 \mu \mathrm{g} / \mathrm{ml}(78.23 \pm 2.91 \%)$ with $\mathrm{IC}_{50}$ value of $6.59 \mu \mathrm{g} / \mathrm{ml}$. Percentage inhibition in $\mathrm{NO}$ production recorded for FXM and FXE at $15 \mu \mathrm{g} / \mathrm{ml}$ was 

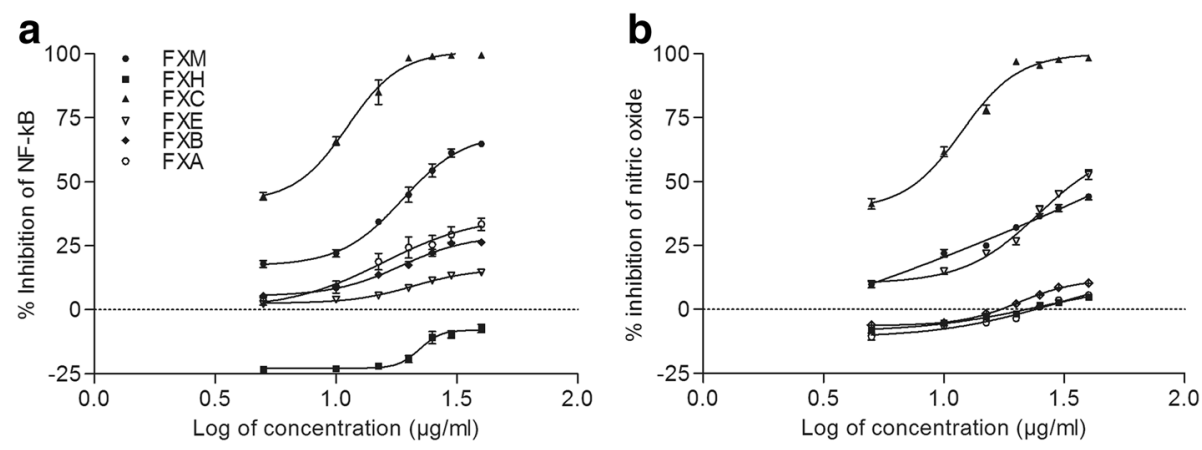

Fig. 1 Dose response curve of NF-kB (a) and nitric oxide (b) synthesis for various extract/fractions of F. xanthoxyloides. FXM Fraxinus xanthoxyloides methanol extract of leaves, FXH Fraxinus xanthoxyloides n-hexane fraction of methanol extract of leaves, FXC Fraxinus xanthoxyloides chloroform fraction of methanol extract of leaves, FXE Fraxinus xanthoxyloides ethyl acetate fraction of methanol extract of leaves, FXB Fraxinus xanthoxyloides n-butanol fraction of methanol extract of leaves, FXA Fraxinus xanthoxyloides residual aqueous fraction of methanol extract of leaves. The values above ' $O$ ' point intersect indicate inhibition while below represent stimulation

$25.06 \pm 1.35 \%, 21.96 \pm 2.71 \%$ respectively. On the other hand FXH, FXE and FXA did not inhibit the synthesis of nitric oxide at the same concentration. As far as the cytotoxicity is concerned FXA induce cytotoxicity at all the concentrations used in this experiment. FXH, FXC and FXE at lower doses (up till $15 \mu \mathrm{g} / \mathrm{ml}$ ) did not cause death of the cells (Fig. 2b).

\section{Time dose response studies}

The FXC was able to effectively inhibit the activity of NFkB and nitric oxide synthesis in the respective assays. On the basis of $\mathrm{IC}_{50}$ obtained for both assays three concentrations; $2 \times \mathrm{IC}_{50}, 1 \times \mathrm{IC}_{50}, 1 / 2 \times \mathrm{IC}_{50}$ were used to estimate the cytotoxicity at various intervals of exposure. The data obtained for time-dose response indicated that these doses did not induce cytotoxicity rather stimulated the respective cells at all the times of treatment.
However all the concentrations reduced the stimulation of cell proliferation with the increase of time (Fig. 3).

\section{Carrageenan induced paw edema}

To demonstrate the anti-inflammatory activity of the extract/fractions of F. xanthoxyloides leaves we have used the carrageenan for induction of edema in hind paw of rat. Rats were treated with carrageenan and various extract/ fractions, and the anti-inflammatory response was assessed by measuring the volume of hind paw over concentration and time (Table 3). Crude extract of F. xanthoxyloides (FXM) and its fractions (FXH, FXC, FXE, FXB, FXA), induced a dose and time dependent reduction in paw edema. Percent anti-inflammatory effects produced after I h of the injection of carrageenan, by FXC $(200 \mathrm{mg} / \mathrm{kg})$ and FXM $(200 \mathrm{mg} / \mathrm{kg})$ were significantly $(P<0.001)$ higher as compared to the diclofenac sodium, standard drug used in this study. However, 2, 3 and $h$ after the carrageenan induced
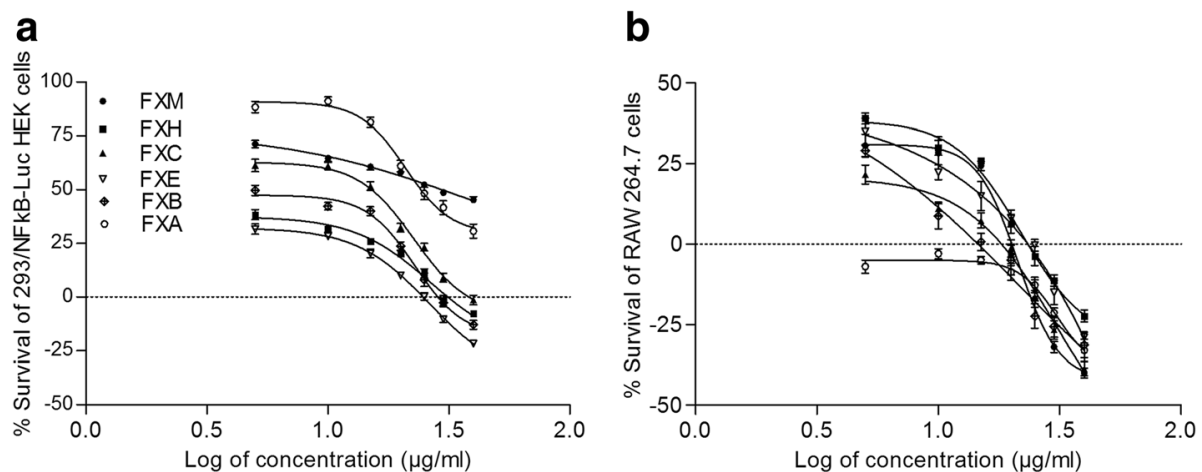

Fig. 2 Dose response curve of \% survival of 293/NFkB-Luc HEK cells (a) and RAW 264.7 cells (b) for various extract/fractions of F. xanthoxyloides. FXM Fraxinus xanthoxyloides methanol extract of leaves, FXH Fraxinus xanthoxyloides n-hexane fraction of methanol extract of leaves, FXC Fraxinus xanthoxyloides chloroform fraction of methanol extract of leaves, FXE Fraxinus xanthoxyloides ethyl acetate fraction of methanol extract of leaves, FXB Fraxinus xanthoxyloides n-butanol fraction of methanol extract of leaves, FXA Fraxinus xanthoxyloides residual aqueous fraction of methanol extract of leaves. The values above ' 0 ' point intersect indicate stimulation while below represent inhibition 

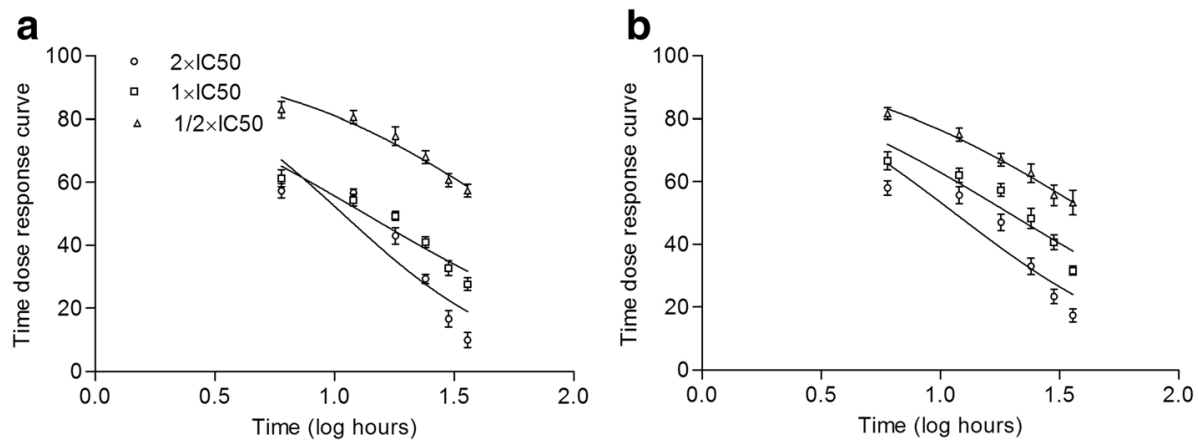

Fig. 3 Time dose response curve of \% survival 293/NFkB-Luc HEK cells (a) and RAW 264.7 cells (b) for various concentration of FXC. All the concentrations exhibited stimulation. ' 0 ' point intersect indicates $100 \%$ survival

Table 3 Effect of FXM and its fractions on carrageenan induced paw edema in rat

\begin{tabular}{|c|c|c|c|c|c|c|}
\hline \multirow[t]{2}{*}{ Treatment } & \multirow[t]{2}{*}{ Dose/route } & \multirow[t]{2}{*}{$\begin{array}{l}\text { Mean paw volume before } \\
\text { carrageenan injection }\end{array}$} & \multicolumn{4}{|c|}{$\begin{array}{l}\text { Increase in paw volume }(\mathrm{ml}) \text { after carrageenan injection (Mean } \pm \text { SD)/Percent } \\
\text { inhibition of edema }\end{array}$} \\
\hline & & & $+1 \mathrm{~h}$ & $+2 \mathrm{~h}$ & $+3 \mathrm{~h}$ & $+4 \mathrm{~h}$ \\
\hline Saline & 2 ml, i.p. & $1.12 \pm 0.08$ & $2.58 \pm 0.09$ & $2.67 \pm 0.09$ & $2.21 \pm 0.09$ & $1.81 \pm 0.11$ \\
\hline \multirow[t]{2}{*}{ FXM } & 100 mg/kg, p.o. & $1.11 \pm 0.08$ & $2.52 \pm 0.06$ & $2.30 \pm 0.09$ & $2.12 \pm 0.20$ & $1.48 \pm 0.08$ \\
\hline & & & $5.88 \pm 1.99^{c}$ & $19.72 \pm 2.39^{\text {cde }}$ & $35.84 \pm 12.89^{c d}$ & $45.28 \pm 4.02^{\mathrm{bc}}$ \\
\hline \multirow[t]{2}{*}{ FXM } & 200 mg/kg, p.o. & $1.17 \pm 0.09$ & $2.44 \pm 0.04$ & $2.05 \pm 0.06$ & $1.92 \pm 0.04$ & $1.45 \pm 0.06$ \\
\hline & & & $15.34 \pm 7.95^{b}$ & $41.07 \pm 5.00^{b}$ & $52.51 \pm 8.30^{b}$ & $58.52 \pm 8.19^{b}$ \\
\hline \multirow[t]{2}{*}{$\mathrm{FXH}$} & 100 mg/kg, p.o. & $1.15 \pm 0.08$ & $2.61 \pm 0.08$ & $2.56 \pm 0.09$ & $2.51 \pm 0.11$ & $1.71 \pm 0.08$ \\
\hline & & & $2.84 \pm 2.42^{c}$ & $4.99 \pm 3.22^{9}$ & $13.44 \pm 5.41^{e}$ & $18.81 \pm 2.21^{e}$ \\
\hline \multirow[t]{2}{*}{$\mathrm{FXH}$} & 200 mg/kg, p.o. & $1.11 \pm 0.05$ & $2.55 \pm 0.05$ & $2.33 \pm 0.06$ & $2.32 \pm 0.05$ & $1.61 \pm 0.04$ \\
\hline & & & $3.96 \pm 2.28^{c}$ & $17.89 \pm 2.03^{\mathrm{de}}$ & $23.29 \pm 4.53^{\text {de }}$ & $27.88 \pm 6.75^{\text {de }}$ \\
\hline \multirow[t]{2}{*}{ FXC } & 100 mg/kg, p.o. & $1.14 \pm 0.06$ & $2.58 \pm 0.06$ & $2.21 \pm 0.06$ & $2.06 \pm 0.13$ & $1.53 \pm 0.08$ \\
\hline & & & $3.85 \pm 1.85^{c}$ & $28.28 \pm 3.11^{c}$ & $42.12 \pm 7.49^{b c}$ & $43.57 \pm 5.21^{b c}$ \\
\hline \multirow[t]{2}{*}{ FXC } & 200 mg/kg, p.o. & $1.09 \pm 0.04$ & $2.17 \pm 0.04$ & $1.71 \pm 0.03$ & $1.53 \pm 0.04$ & $1.25 \pm 0.04$ \\
\hline & & & $29.19 \pm 4.60^{a}$ & $59.67 \pm 3.23^{\mathrm{a}}$ & $73.29 \pm 2.65^{\mathrm{a}}$ & $77.64 \pm 3.04^{a}$ \\
\hline \multirow[t]{2}{*}{ FXE } & 100 mg/kg, p.o. & $1.12 \pm 0.07$ & $2.59 \pm 0.06$ & $2.47 \pm 0.04$ & $2.34 \pm 0.06$ & $1.55 \pm 0.08$ \\
\hline & & & $1.71 \pm 0.82^{c}$ & $8.76 \pm 3.66^{f g}$ & $22.32 \pm 6.02^{\mathrm{de}}$ & $36.22 \pm 8.23^{c d}$ \\
\hline \multirow[t]{2}{*}{ FXE } & 200 mg/kg, p.o. & $1.12 \pm 0.06$ & $2.56 \pm 0.07$ & $2.25 \pm 0.05$ & $2.18 \pm 0.05$ & $1.49 \pm 0.05$ \\
\hline & & & $4.08 \pm 1.78^{c}$ & $23.60 \pm 2.10^{c d}$ & $32.38 \pm 4.66^{\mathrm{cd}}$ & $45.77 \pm 4.22^{\mathrm{bc}}$ \\
\hline \multirow[t]{2}{*}{ FXB } & 100 mg/kg, p.o. & $1.11 \pm 0.06$ & $2.59 \pm 0.04$ & $2.50 \pm 0.05$ & $2.32 \pm 0.07$ & $1.62 \pm 0.07$ \\
\hline & & & $1.49 \pm 1.71^{c}$ & $6.25 \pm 1.15^{\mathrm{fg}}$ & $23.07 \pm 4.45^{\mathrm{de}}$ & $25.68 \pm 3.08^{\text {de }}$ \\
\hline \multirow[t]{2}{*}{ FXB } & 200 mg/kg, p.o. & $1.11 \pm 0.06$ & $2.55 \pm 0.07$ & $2.30 \pm 0.06$ & $2.19 \pm 0.08$ & $1.52 \pm 0.06$ \\
\hline & & & $3.63 \pm 1.31^{c}$ & $19.84 \pm 3.34^{\text {cde }}$ & $31.08 \pm 5.33^{\mathrm{cd}}$ & $39.89 \pm 7.36^{\mathrm{cd}}$ \\
\hline \multirow[t]{2}{*}{ FXA } & 100 mg/kg, p.o. & $1.10 \pm 0.06$ & $2.58 \pm 0.06$ & $2.48 \pm 0.09$ & $2.50 \pm 0.08$ & $1.70 \pm 0.05$ \\
\hline & & & $1.60 \pm 1.16^{c}$ & $7.05 \pm 2.71^{\mathrm{fg}}$ & $11.17 \pm 2.82^{\mathrm{e}}$ & $13.18 \pm 3.04^{e}$ \\
\hline \multirow[t]{2}{*}{ FXA } & 200 mg/kg, p.o. & $1.12 \pm 0.06$ & $2.59 \pm 0.05$ & $2.39 \pm 0.04$ & $2.36 \pm 0.07$ & $1.63 \pm 0.01$ \\
\hline & & & $1.82 \pm 1.64^{c}$ & $14.47 \pm 4.31^{\mathrm{ef}}$ & $20.80 \pm 2.55^{\text {de }}$ & $24.94 \pm 7.76^{\text {de }}$ \\
\hline \multirow[t]{2}{*}{ Diclofenac sodium } & 10 mg/kg, i.p. & $1.13 \pm 0.08$ & $2.57 \pm 0.05$ & $1.63 \pm 0.05$ & $1.46 \pm 0.08$ & $1.24 \pm 0.04$ \\
\hline & & & $4.08 \pm 2.47^{c}$ & $67.32 \pm 4.25^{\mathrm{a}}$ & $80.54 \pm 2.61^{a}$ & $85.23 \pm 7.71^{\mathrm{a}}$ \\
\hline
\end{tabular}

FXM F. xanthoxyloides methanol extract, FXH F. xanthoxyloides n-hexanefraction, FXC F. xanthoxyloides chloroform fraction, FXE F. xanthoxyloides ethyl acetate fraction, FXB F. xanthoxyloides $n$-butanol fraction, FXA F. xanthoxyloides residual aqueous fraction. Data values shown represent mean \pm SD $(n=6)$. One-way ANOVA followed by Tukey's HSD multiple comparison tests. Percentage inhibition is shown in brackets. Different superscript alphabets in each column indicate difference at $P<0.05$ 
paw edema, FXC $(200 \mathrm{mg} / \mathrm{kg})$ exhibited statistically similar $(P>0.001)$ percent inhibition of edema to that of the diclofenac sodium. The following order of edema inhibition FXM $>$ FXE $>$ FXB $>$ FXH $>$ FXA was recorded for rest of the fractions at the maximum dose $(200 \mathrm{mg} / \mathrm{kg})$ after $4 \mathrm{~h}$ of the carrageenan treatment.

\section{Subcutaneous air pouch assay}

\section{Effect of FXC on the hematology of air pouch exudate}

In this study both doses of FXC significantly $(P<0.001)$ decreased the count of neutrophils, monocytes, lymphocytes and WBCs in the exudate of air pouch induced with carrageenan (Table 4). Decrease in the number of neutrophils and monocytes in the exudate treated with FXC at $200 \mathrm{mg} / \mathrm{kg}$ and diclofenac sodium was statistically $(P>0.001)$ similar to each other. However, number of lymphocytes and WBCs in the exudate was more markedly $(P<0.001)$ decreased to that of the diclofenac sodium treated rats.

\section{Effect of FXC on inflammatory mediators of air pouch exudate}

The results obtained for the alteration in inflammatory mediators of air pouch exudate are presented in Table 5. The results indicated a dose dependent decrease in the inflammatory mediators; TNF- $\alpha$, IL- $6, \mathrm{NO}$ and $\mathrm{PGE}_{2}$ with FXC in the exudate of air pouch of rat induced with carrageenan injection. In this experiment generally a dose dependent decrease in the level of inflammatory mediators with FXC was recorded in the air pouch exudate of rat. Level of TNF- $\alpha$ and NO in the air pouch exudate was found higher at $200 \mathrm{mg} / \mathrm{kg}$ of FXC treatment but was statistically $(P>0.001)$ similar to that of the diclofenac sodium treatment. On the other hand the level of IL- 6 and PGE 2 was recorded at lower level but statistically $(P>0.001)$ similar as compared to the diclofenac sodium treatment.

\section{Gas chromatography-mass spectrometry of FXM}

In the crude methanol extract of $F$. xanthoxyloides, 30 compounds were detected through GC-MS analysis (Table 6). The chromatogram showed prominent peaks in the retention time range 3.80-38.54 (Fig. 1). The GCMS analysis provided six major peaks determining the presence of 15 major classes of compounds contributing three terpenoids (26.61\%), four lactam (16.47\%), three esters $(15.81 \%)$, three phenols (8.37\%), two steroid (6.91\%), three alcohols (5.02 \%), three ketones (4.49\%), one aldehyde (3.89\%), two fatty acid glycerol (3.01\%), one nitrile $(2.64 \%)$, two lactones $(2.31 \%)$, one silyl-ether $(2.25 \%)$, one alkene $(1.31 \%)$ and one alkyne $(0.89 \%)$.

\section{Discussion}

Nowadays it is an accepted view that an unbalanced diet, environmental stresses and related anomalies increased the inclination of the affected individuals towards the chronic ailments such as cardiovascular, arthritis and diabetes [48]. Inflammation, pain and associated symptoms are all attributed to the elevated level of prostaglandins, tumor necrosis factor and interleukins [2]. To evaluate the peripheral analgesia of drugs or herbal products, acetic acid induced pain model is mostly used as it involves the peripheral nociceptors. Enhanced level of free arachidonic acid, prostaglandins especially $\mathrm{PGE}_{2}$ and $\mathrm{PGE}_{2} \alpha$, and lipoxygenase in the peritoneal fluid, produce pain sensation as an inflammatory effect of acetic acid. Writhing paradigm is elicited due to stimulation of pain at nerve endings on account of swelling and vascular permeability. Activity of COX is decreased due to NSAIDs such as diclofenac sodium in the peripheral tissues results in inhibition of transduction of key afferent nociceptors [49]. In our study count of writhes was decreased in a dose dependent fashion and was dominantly decreased at $200 \mathrm{mg} / \mathrm{kg}$, p.o. of FXC which was comparable to the standard drugs diclofenac sodium and aspirin (Table 1). From these results it can be hypothesized that FXC might possess some pharmacologically active metabolites that interfere with the synthesis of prostaglandins. However, it is worthwhile to investigate the exact metabolic event where the extract exerts its anti-nociceptive effects.

Treatment of rats with FXC at $200 \mathrm{mg} / \mathrm{kg}$, p.o. in hot plate thermal stimulation model, exhibited beneficial analgesic effects at $120 \mathrm{~min}$ after treatment. In general the

Table 4 Effect of FXC on the hematology $\left(\times 10^{3} / \mu l\right)$ in carrageenan induced exudate in the air pouch

\begin{tabular}{llllll}
\hline & Dose/route & Neutrophils & Monocytes & Lymphocytes & WBCs \\
\hline Saline & $2 \mathrm{ml}$ i.p. & $0.150 \pm 0.009^{\mathrm{d}}$ & $0.079 \pm 0.010^{\mathrm{d}}$ & $0.472 \pm 0.040^{\mathrm{d}}$ & $0.945 \pm 0.0982^{\mathrm{d}}$ \\
Carrageenan & $10 \mathrm{ml} / \mathrm{kg} \mathrm{p.o.}$ & $6.027 \pm 0.350^{\mathrm{a}}$ & $1.972 \pm 0.136^{\mathrm{a}}$ & $12.665 \pm 1.456^{\mathrm{a}}$ & $23.422 \pm 1.556^{\mathrm{a}}$ \\
Diclofenac sodium & $10 \mathrm{mg} / \mathrm{kg} \mathrm{p.O.}$ & $4.494 \pm 0.172^{\mathrm{c}}$ & $1.445 \pm 0.114^{\mathrm{bc}}$ & $10.978 \pm 1.231^{\mathrm{b}}$ & $17.521 \pm 1.201^{\mathrm{b}}$ \\
FXC & $100 \mathrm{mg} / \mathrm{kg} \mathrm{p.o.}$ & $5.082 \pm 0.238^{\mathrm{b}}$ & $1.665 \pm 0.125^{\mathrm{b}}$ & $9.240 \pm 0.857^{\mathrm{b}}$ & $16.932 \pm 0.974^{\mathrm{b}}$ \\
FXC & $200 \mathrm{mg} / \mathrm{kg}$ p.o. & $4.285 \pm 0.153^{\mathrm{c}}$ & $1.353 \pm 0.122^{c}$ & $5.698 \pm 0.483^{c}$ & $12.199 \pm 1.571^{c}$ \\
\hline
\end{tabular}

FXC $=$ F. xanthoxyloides chloroform fraction. Count of cells is presented as mean $\pm \mathrm{SD}(n=6)$. One way analysis of variance for count of cells was followed by multiple comparisons by Tukeys' HSD test. Superscript alphabets indicate significance among treatments $(P<0.001)$ on not sharing common letter 
Table $\mathbf{5}$ Inhibitory effect of FXC on inflammatory mediators in exudate of air pouch

\begin{tabular}{|c|c|c|c|c|c|}
\hline & \multirow[b]{2}{*}{ Dose/route } & \multirow[b]{2}{*}{ TNF-a (pg/ml) } & \multicolumn{3}{|c|}{ Estimated values/(Percent inhibition) } \\
\hline & & & IL-6 (pg/ml) & $\mathrm{NO}(\mu \mathrm{M} / \mathrm{ml})$ & $\mathrm{PGE}_{2}(\mathrm{pmole} / \mathrm{ml})$ \\
\hline Saline & $2 \mathrm{ml}$ i.p. & $5.50 \pm 1.04^{d}$ & $27.66 \pm 5.00^{c}$ & $0.443 \pm 0.058^{d}$ & $1301.8 \pm 90.87^{b}$ \\
\hline Carrageenan & 10 ml/kg p.o. & $964.50 \pm 95.525^{\mathrm{a}}$ & $6291.3 \pm 562.77^{\mathrm{a}}$ & $0.784 \pm 0.105^{\mathrm{a}}$ & $1525.7 \pm 75.76^{\mathrm{a}}$ \\
\hline \multirow[t]{2}{*}{ Diclofenac sodium } & 10 mg/kg p.o. & $418.50 \pm 57.83^{c}$ & $4544.8 \pm 235.87^{b}$ & $0.362 \pm 0.043^{c}$ & $1339.7 \pm 25.17^{\mathrm{b}}$ \\
\hline & & $56.44 \pm 6.01$ & $34.03 \pm 3.42$ & $56.11 \pm 4.99$ & $7.69 \pm 1.73$ \\
\hline \multirow[t]{2}{*}{ FXC } & 100 mg/kg p.o. & $592.33 \pm 45.31^{b}$ & $5146.2 \pm 257.58^{b}$ & $0.605 \pm 0.060^{b}$ & $1404.7 \pm 21.37^{\mathrm{ab}}$ \\
\hline & & $38.35 \pm 4.71$ & $25.30 \pm 3.73$ & $26.71 \pm 7.33$ & $3.21 \pm 1.47$ \\
\hline \multirow[t]{2}{*}{ FXC } & 200 mg/kg p.o. & $505.67 \pm 36.037^{b c}$ & $4398.2 \pm 159.46^{b}$ & $0.408 \pm 0.049^{b c}$ & $1309.8 \pm 30.46^{b}$ \\
\hline & & $47.37 \pm 3.75$ & $36.16 \pm 2.31$ & $50.52 \pm 5.96$ & $9.74 \pm 2.09$ \\
\hline
\end{tabular}

FXC F. xanthoxyloides chloroform fraction, tumor necrosis factor- a (TNF-a), interleukin-6 (IL-6), nitric oxide (NO), prostaglandin $E_{2}\left(\mathrm{PGE}_{2}\right)$. Count of cells is presented as mean \pm SD $(n=6)$. One way analysis of variance for inflammatory mediators was followed by multiple comparisons by Tukeys' HSD test. Superscript alphabets indicate significance among treatments $(P<0.001)$ on not sharing common letter

Table 6 GC-MS analysis of FXM

\begin{tabular}{|c|c|c|c|}
\hline & Compound name & Area \% & Class \\
\hline 1. & 7-(diphenylmethylene) -6-phenylbicyclo [3.2.0] hept-2-en-endo-6-ol & 2.32 & Alcohol \\
\hline 2. & 1-[1-(Bromomethyl) 2 (2,2,2-trichloroethyl) cyclopent-5-y-1]-(1H,3H)-5-methyl-pyrimidine-2,4-dione & 1.15 & $\delta$ Lactam \\
\hline 3. & 2,2-Dimethyl-5-(2',2'-dideuterio-1'-indanyldene)-1,3-dioxane-4,6-dion & 1.00 & Lactone \\
\hline 4. & 3-Heptene, (E)- (CAS) & 1.31 & Alkene \\
\hline 5. & (S)-(-)-2-(Methoxymethoxy) propan-1-al & 3.89 & Aldehyde \\
\hline 6. & (S)-5-(1-Hydroxy-1-methylethyl)-2-pyrrolidinone & 4.13 & Y Lactam \\
\hline 7. & 1-(3,6,6-Trimethyl-1,6,7,7a-tetrahydrocyclopenta [c] pyran-1-yl)ethanone & 2.10 & Ketone \\
\hline 8. & Phenol, 4-nitroso- (CAS) & 1.78 & Phenol \\
\hline 9. & 1-(0-Methoxyphenyl)-3-Buten-1-ol & 1.04 & Alcohol \\
\hline 10. & 5-Isopropyl-4 (trifluoromethyl)-1H-pyrimidin-2-one & 7.28 & $\delta$ Lactam \\
\hline 11. & 9-Hydroxy-1-methyl-1,2,3,4-tetrahydro-8 h-pyrido (1,2-A) pyrazin-8-one & 0.85 & Ketone \\
\hline 12. & á-ionol & 1.66 & Alcohol \\
\hline 13. & Methyl (E)-5-(2 Oxocyclopentyl)-2-pentenoate ethylene ketal & 2.61 & Ester \\
\hline 14. & 4-((1E)-3-Hydroxy-1-propenyl)-2-methoxyphenol & 5.44 & Phenol \\
\hline 15. & (E)-3-(3'-hydroxy-2',6',6'-trimethyl-1'-cyclohexen-1'-yl propionic acid methyl ester & 11.98 & Ester \\
\hline 16. & Isoquinolinium bis (ethoxycarbonyl) methylide & 1.22 & Ester \\
\hline 17. & 1-Cyclododecanone, 2-ethylidene & 1.54 & Ketone \\
\hline 18. & 3,5-Dimethoxy-p-coumaric alcohol & 1.15 & Phenol \\
\hline 19. & 2-Hexadecen-1-ol,3,7,11,15-tetramethyl-,[R-[R*, $R^{*}$-(E)]] (CAS) or (Phytol) & 4.92 & Diterpene \\
\hline 20. & 2,4,6-Trimethoxyisophthalonitrile & 2.64 & Nitrile \\
\hline 21. & 1-Phenyl-2-(3',4',5' trimethoxyphenyl) ethyne & 0.89 & Alkyne \\
\hline 22. & 2H-Pyran-2-one, tetrahydro-6-tridecyl- (CAS) & 1.31 & Lactone \\
\hline 23. & Pyrimidine, 5-methyl-2,4-bis[(trimethylsilyl)oxy]- (CAS) & 2.25 & Silylether \\
\hline 24. & 2-palmitoyl glycerol & 1.32 & Fatty acid glycerol \\
\hline 25. & Gusation A & 3.91 & Lactam \\
\hline 26. & 2-linoleoyl glycerol & 1.69 & Fatty acid glycerol \\
\hline 27. & Cholest-5-ene-1,3,16-triol, (1à,3á,16á)- (CAS) & 1.08 & Steroid \\
\hline 28. & Squalene & 18.95 & Triterpene \\
\hline 29. & Stigmasta-5,22-dien-3-ol, (3á,22E)- (CAS) & 5.83 & Steroid \\
\hline 30. & 6,10,14,18,22-Tetracosapentaen-2-ol 3-bromo 2,6,10,15,19,23-hexamethyl-, (all-E)- & 2.74 & Terpenoid \\
\hline
\end{tabular}


analgesic effect recorded was dose dependent and the latency time was enhanced by increase of time for all the test samples (Table 2). Thermal nociception model such as hot plate provide valuable clues about the analgesic activity of the test samples. The analgesic effect recorded in this study might involve the same mechanism of action; activation of opioid receptors, by the test samples similar to the diclofenac sodium. On account of apparent similarity of the analgesic effect of the test samples and the diclofenac sodium, implicate that test samples behave as narcotic analgesic and might work in the same manner to reduce pain sensation as diclofenac sodium [49]. In this study the diclofenac sodium and morphine $(10 \mathrm{mg} / \mathrm{kg}$, i.p.) exhibited the analgesic threshold after $30 \mathrm{~min}$ and more or less attained the maximum level after $60 \mathrm{~min}$ of treatment. However, FXC $(200 \mathrm{mg} / \mathrm{kg}$, p.o.) attained the maximum analgesic threshold after $120 \mathrm{~min}$ of treatment. Secondly, FXC (200 mg/kg, p.o.) exhibited higher analgesic activity to that of morphine, $120 \mathrm{~min}$ after the treatment. These results implicated a difference of action between the morphine and the test samples, as the herbal extracts constitute varied combination of metabolites. The active metabolites of the FXC might interfere with the release of pain mediators.

$\mathrm{NFkB}$ is an inducible transcription factor that regulates the fate of cells such as programmed cell death, proliferation control, cell invasion and in tumorigenesis. Over expression of NFkB through TNF- $\alpha$ during in vitro conditions provides an opportunity to unravel the potential of natural products to inhibit the immune response provoked by a variety of stresses. In this study, 293/NFkBLuc HEK cells were stimulated by TNF- $\alpha$ for the synthesis of NFkB in the presence of FXM and its fractions; FXH, FXC, FXE, FXB and FXA at 0.5,10, 15, 20, 25, 30, $40 \mu \mathrm{g} /$ $\mathrm{ml}$ concentration (Fig. 1a). Among the extract/fractions, FXC has shown the highest inhibitory activity at $15 \mu \mathrm{g} / \mathrm{ml}$ $85.00 \pm 8.12 \%\left(\mathrm{IC}_{50}=5.98 \mu \mathrm{g} / \mathrm{ml}\right)$ against NFkB followed by FXM $\left(34.46 \pm 1.22 \%, \mathrm{IC}_{50}=23.01 \mu \mathrm{g} / \mathrm{ml}\right)$ whereas FXH $(-21.80 \pm 1.22 \%)$ enhanced the synthesis of NFkB. It is conceivable that FXC might inhibit certain stimuli such as oxidative damage or inflammatory cytokines as a mechanism to inhibit NFkB signaling. Strong anti-NFkB activity has also been determined in chloroform fraction of Carpinus tschonoskii leaves [50]. Further, in this study cytotoxicity was not induced with the extract/fractions of $F$. xanthoxyloides at the same dose level. In addition, inhibition of NFkB signaling is considered to be an effective step in anticancer properties because up-regulation of NFkB suppresses apoptosis [51]. The results obtained in this study suggest the therapeutic importance of FXC and FXM as a natural remedy for various inflammatory disorders [52].

Early stages of inflammation predominantly results in the up-regulation of inducible enzymes such as COX-2 and iNOS which subsequently enhance the release of proinflammatory mediators such as TNF- $\alpha$ and NO [1]. Nitric oxide is one of the factors involved in the propagation of inflammatory responses. It also mediates a variety of functions involving vascular homeostasis, neurotransmission and host defense [1]. Nitric oxide is highly reactive molecule that act as an important mediator and regulator of inflammatory responses. Nitric oxide has the potential to react with superoxide anion to produce the highly reactive, free radical peroxynitrite which can cause irreversible damage to cell membranes, leading to cell death and tissue damage [53]. Nitric oxide induced oxidative stress is one the causal agent towards many chronic ailments such as diabetes, vascular disorders, and Parkinson's disease [54]. In the presence of such disorders altering the macrophage nitric oxide synthesis could potentially attenuates a variety of inflammatory mediators. LPS-stimulated macrophage model was used in this study to investigate the efficacy of the tested samples. The results exhibited that FXC at $15 \mu \mathrm{g} / \mathrm{ml}$ was highly effective in inhibiting the generation of nitric oxide $\left(78.23 \pm 2.90 \%, \mathrm{IC}_{50}=6.59 \mu \mathrm{g} / \mathrm{ml}\right)$ whereas no considerable inhibitory activity at the same dose was detected in crude extract and other fractions (Fig. 1b). Inhibition of nitric oxide production in LPSinduced nitric oxide model with chloroform fraction of Cudrania tricuspidata [55] and with extract of Salvia officinalis in RAW 264.7 macrophages have been reported earlier [1].

Carrageenan, phlogistic agent, is widely used to induce paw edema in rodents to demonstrate anti-inflammatory effect of drugs or herbs. Carrageenan when injected in the rat paw it induces severe edema that is discernible within $30 \mathrm{~min}$ [56]. In the present investigation test samples at 100 and $200 \mathrm{mg} / \mathrm{kg}$, p.o. were subjected for their antiinflammatory activity in a carrageenan-induced paw edema model in rat. FXC at dose level of $200 \mathrm{mg} / \mathrm{kg}$, p.o. efficiently inhibited the edema formation at 1 st, 2nd, 3rd and 4th $\mathrm{h}$ after the treatment. The antiinflammatory activity of FXC was recorded significantly $(P<0.001)$ higher to the drugs diclofenac sodium, at $1 \mathrm{~h}$ after the treatment. The lower dose $(100 \mathrm{mg} / \mathrm{kg}$, p.o.) of FXM and FXC while, higher dose (200 mg/kg, p.o.) of FXE and FXB exerted moderate anti-inflammatory activity (Table 3). Carrageenan-induced inflammation is considered to be a biphasic model. Initial stage (1-2 h) contributes to the release of histamine, bradykinin and serotonin which mediates the increased synthesis of prostaglandins from surrounding tissues of the injured area [49]. During second phase (3-4 h) inflammation is sustained by the perpetual release of prostaglandins [57]. In this phase COX-2 enzyme plays a key role to sustain inflammation by converting arachidonic acid into prostaglandins. These substances are responsible for the formation of inflammatory exudates. Most of 
the NSAIDs, such as diclofenac sodium do not inhibit the formation of pro-inflammatory mediators and substances of the primary phase whereas target the COX-2 enzyme and inhibit the paw edema during later stage of inflammatory response [57]. In this study FXM and FXC inhibited the paw edema in both phases $(0-4 \mathrm{~h})$, suggesting the stabilization of the lysosomal membrane during initial phase which in turn inhibit the release of inflammatory mediators. The efficient inhibition of inflammation by FXC, FXM and moderate inhibition of inflammation by FXE and FXB at $200 \mathrm{mg} / \mathrm{kg}$ dose has been determined during late phase after carrageenan treatment. It can be speculated that active leads present in the extract/fraction might inhibit the activity of COX enzyme thereby attenuates the conversion of arachidonic acid to prostaglandins. Although the mechanism of edema inhibition of $F$. xanthoxyloides during early phase in not known, it might be attributed by the inhibition of NO production and NFkB signaling as we have determined during in vitro studies. On the basis of these observations we may assume that diverse active phyto-constituents present in FXC show non-selective interaction, greater half-life and synergistic effects towards the inhibition of inflammatory response.

On account of significant anti-inflammatory activity during in vitro and in vivo experiments, FXC was used in the air pouch inflammatory model to assess its antiinflammatory potential on the inflammatory mediators and the leukocyte count. Development of air pouch in rat resembles the inflamed synovial membrane of patients with rheumatoid arthritis. In this experiment the increase in the count of neutrophils, monocytes, leukocytes and the WBCs in the air pouch exudate with carrageenan was substantially decreased $(P<0.001)$ with both the doses of FXC (Table 4). The migration of polymorphonuclear leukocytes in the pouch was inhibited by FXC and the effect produced by the higher dose of FXC (200 mg/kg) was similar to the diclofenac sodium. The migration of leukocytes towards the injured area is coupled with the release of inflammatory mediators such as NO, IL- 6 and TNF- $\alpha$ [58]. In the air pouch exudate substantial increase in the level of these inflammatory mediators has been recorded indicating the development of inflammation at the injured site in rat (Table 5). However, the marked decrease in carrageenan induced accumulation of NO, IL- 6 and TNF- $\alpha$ by FXC in the air pouch exudate reflected the repairing potential of the FXC. In general the enhanced level of NO at the inflamed site is usually achieved by activation of the inducible nitrate synthase (iNOS) activity. The results obtained in this study suggested that the blockage of TNF- $\alpha$ NO pathway by FXC might occur through the inhibition of inducible nitrate synthase (iNOS) activity.

Prostaglandins at the injured area are produced as an effect of COX-2 from arachidonic acid and are considered to be involved in the endurance of inflammation, pain and pyrexia [59]. In the air pouch exudate the level of $\mathrm{PGE}_{2}$ was markedly elevated in the carrageenan treated rats. However, the use of FXC to carrageenan treated rats markedly inhibited the release of $\mathrm{PGE}_{2}$ in the air pouch exudate. These results suggest that the decreased level of $\mathrm{PGE}_{2}$ with $\mathrm{FXC}$ in the carrageenan induced air pouch exudate can either be achieved through the inhibition of COX-2 enzyme and/or the suppression of inflammation related cellular activities.

Our results of acute toxicity studies suggest that the crude extract of the leaves of F. xanthoxyloides and its fractions was safe in and non-toxic to rats at $3000 \mathrm{mg} / \mathrm{kg}$ dosages. So the use of 100 and $200 \mathrm{mg} /$ $\mathrm{kg}$ of the extract/fractions was selected for various in vivo studies.

Phytochemical profile obtained through GC-MS analysis indicated that FXM is comprised of varied compounds belonging to 15 major classes (Table 6). The retention times obtained for various constituents are presented in Fig. 4. The main class was comprised of terpenoids, and the rest of the classes include the lactams, esters, phenols, steroids, alcohols, and ketones. The anti-inflammatory activity of the extract/fractions might be attributed due the presence of sterols and terpenoids [60]. The difference in activity of the extract/fractions obtained in this study might involve the varied combination of compounds and their concentration in the respective extract or fraction. Among the phyto-constituents reported through GC-MS analysis; squalene is natural triterpenoid that targets proinflammatory mediators, modulate NFkB signaling and prevent over activation of macrophages, neutrophils and monocytes. It has exhibited anti-inflammatory activities in the LPS-mediated inflammatory response [61]. 2-linoleoyl glycerol has the potential to attenuate the allergic diseases [62]. Use of 2-palmitoyl glycerol and 2-linoleoyl glycerol exhibited synergistic effect in the binding of 2arachidonoyl glycerol for binding to the cannabinoid receptor $2(\mathrm{CB}-2)$ thus enhancing anti-nociceptive activities [63]. HPLC-DAD analysis of FXM indicated the existence of rutin and caffeic acid (data not shown). Oral administration of rutin significantly reduced the carrageenan induced paw edema in rat and also the migration of neutrophils [64]. Administration of rutin reduced the paw edema volume in adjuvant-carrageenan-induced inflammation in rats [65]. Palmitic acid induced inflammation on cultured macrophages and development of fatty liver in high fat fed diet in mice was suppressed with rutin treatment [66]. Caffeic acid reduces the acute immune and inflammatory response [67]. Anti-inflammatory and anti-coagulatory activities of caffeic have also been reported [68]. Studies suggest that caffeic acid also possesses antitumor abilities [69]. 


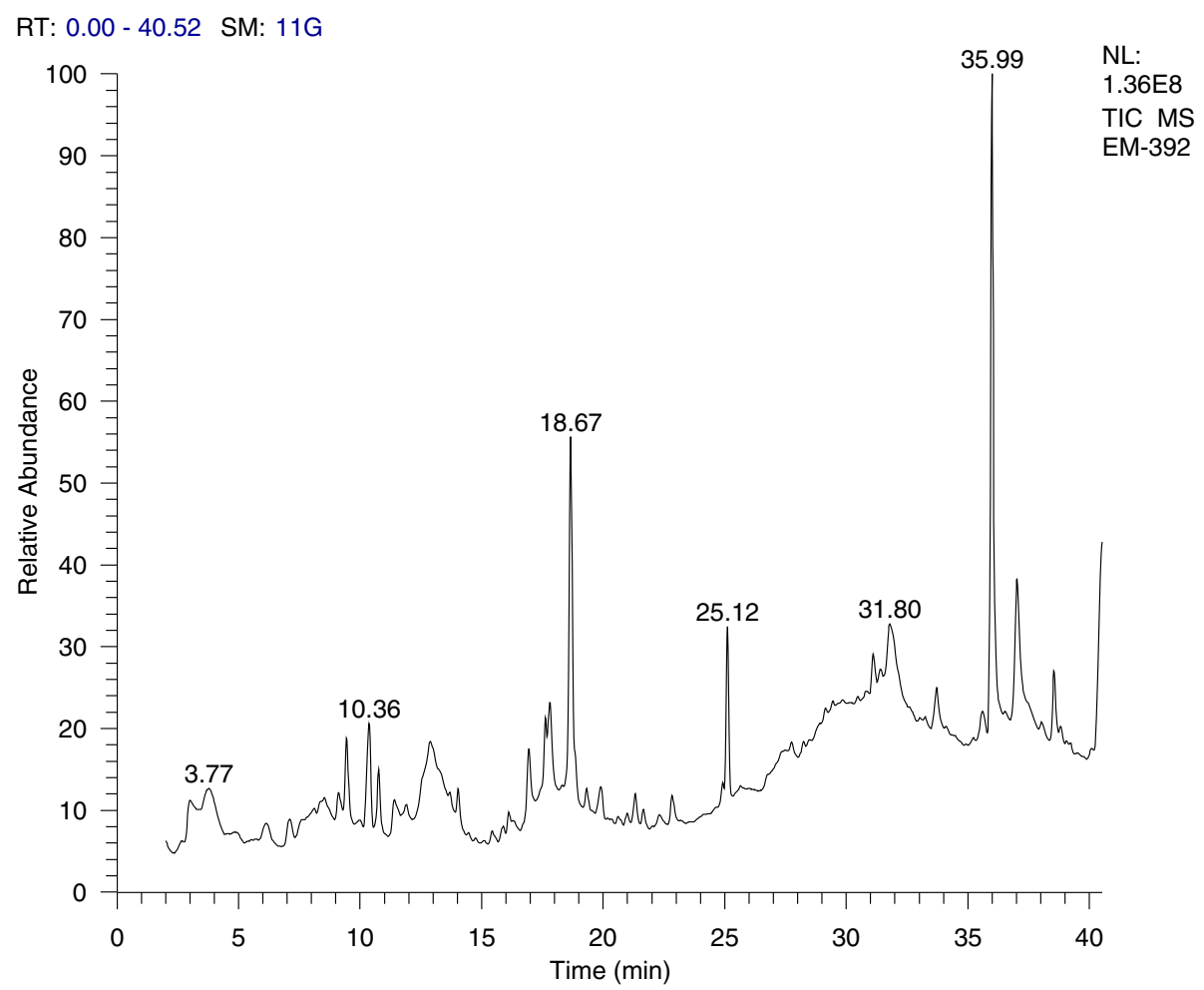

Fig. 4 GC-MS analysis of the methanol extract of F. xanthoxyloides

\section{Conclusion}

On the basis of the results obtained in this study it can be speculated that plant has the ability to inhibit the LPS, TNF- $\alpha$ and carrageenan induced stimulatory responses, acetic acid and hot plate induced pain responses. The chloroform fraction (FXC) exhibited significant antiinflammatory activities during in vitro and in vivo studies suggesting its therapeutic importance in inflammation related disorders.

\footnotetext{
Abbreviations

COX, cyclooxygenase; FXA, Fraxinus xanthoxyloides residual aqueous fraction of methanol extract of leaves; FXB, Fraxinus xanthoxyloides n-butanol fraction of methanol extract of leaves; FXC, Fraxinus xanthoxyloides chloroform fraction of methanol extract of leaves; FXE, Fraxinus xanthoxyloides ethyl acetate fraction of methanol extract of leaves; FXH, Fraxinus xanthoxyloides $n$-hexane fraction of methanol extract of leaves; FXM, Fraxinus xanthoxyloides methanol extract of leaves; IL, interleukins; iNOS, indicible nitric oxide synthase; LPS, lipopolysaccharides; NFkB, necrosis factor kappa B; NO, nitric oxide; PG, prostaglandin; TNF-a, tumor necrosis factor -alpha
}

\section{Acknowledgements}

We acknowledge Higher Education Commission (HEC) of Pakistan for awarding indigenous scholarship to the first author.

\section{Funding}

The project was partially funded by the Higher Education Commission (HEC) of Pakistan by awarding indigenous scholarship to the first author.

\section{Availability of data and materials}

All the data is contained in the manuscript.

\section{Authors' contributions}

TY made significant contribution to experimentation, acquisition and drafting of the manuscript. MRK has made substantial contribution to designing, analyzing and drafting of the manuscript. MS made a contribution in the experimentation and acquisition of the data. All authors read and approved the final manuscript.

\section{Authors' information}

MRK did his Diploma in Unani Medicine and Surgery (DUMS) and is a registered practitioner of the National Council for Tibb of Pakistan. He is working as Associate Professor at the Department of Biochemistry, Quaid-iAzam University, Islamabad, Pakistan.

\section{Competing interest}

The authors declare that they have no competing interest.

\section{Consent for publication}

Not applicable.

Ethics approval and consent to participate

This study makes use of rats and the experimental protocol for the use of animal was approved (Bch\#0263) by the ethical board of Quaid-i-Azam University, Islamabad Pakistan.

\section{Author details}

'Department of Biochemistry, Faculty of Biological Sciences, Quaid-i-Azam University, Islamabad 45320, Pakistan. '2Department of Biosciences, COMSATS Institute of Information Technology, Islamabad, Pakistan.

Received: 5 November 2015 Accepted: 1 July 2016

Published online: 19 July 2016

\section{References}

1. Mueller M, Hobiger S, Jungbauer A. Anti-inflammatory activity of extracts from fruits, herbs and spices. Food Chem. 2010;122:987-96. 
2. Labonte AC, Tosello-Trampont A-C, Hahn YS. The role of macrophages polarization in infectious and inflammatory diseases. Mol Cells. 2014;37:275-85.

3. Theoharides TC, Alysandratos K-D, Angelidou A, Delivanis D-A, Sismanopoulos N, Zhang B, Asadi S, Vasiadi M, Weng Z, Miniati A, Kalogeromitros D. Mast cells and inflammation. Biochim Biophys Acta (BBA) - Mol Basis of Dis. 2012;1822:21-33.

4. Bokhari J, Khan MR. Evaluation of anti-asthmatic and antioxidant potential of Boerhavia procumbens in toluene diisocyanate (TDI) treated rats. J Ethnopharmacol. 2015;172:377-85.

5. Reuter S, Gupta SC, Chaturvedi MM, Aggarwal BB. Oxidative stress, inflammation, and cancer: how are they linked. Free Radic Biol Med. 2010;49:1603-16.

6. Yu T, Lee J, Lee YG, Byeon SE, Kim MH, Sohn EH, Lee YJ, Lee SG, Cho JY. In vitro and in vivo anti-inflammatory effects of ethanol extract from Acer tegmentosum. J Ethnopharmacol. 2010;128:139-47.

7. White M. Mediators of inflammation and inflammatory process. J Aller Clin Immunol. 1999;103:S378-81.

8. Kumar S, Ganachari MS, Nagoor BVS. Anti-inflammatory activity of Ziziphus jujuba L leaves extract in rats. J Nat Remedy. 2004;4:183-5.

9. Dharmasiri M, Jayakody J, Galhena G, Liyanage S, Ratnasooriya W. Antiinflammatory and analgesic activities of mature fresh leaves of Vitex negundo. J Ethnopharmacol. 2003;87(2):199-206.

10. Kidd BL, Urban LA. Mechanisms of inflammatory pain. Br J Anaesth. 2001; 87:3-11.

11. Goswami SK, Wan D, Yang J, da Silva CAT, Morisseau C, Kodani SD, Yang G$Y$, Inceoglu B, Hammock BD. Anti-ulcer efficacy of soluble epoxide hydrolase inhibitor TPPU on diclofenac sodium induced intestinal ulcers. J Pharmacol Exp Ther. 2016;116:232108.

12. Habib M, Waheed I. Evaluation of anti-nociceptive, anti-inflammatory and antipyretic activities of Artemisia scoparia hydromethanolic extract. J Ethnopharmacol. 2013;145(1):18-24.

13. Radner H, Ramiro S, Buchbinder R, Landewé R, Van Der Heijde D, Aletaha D. Pain management for inflammatory arthritis (rheumatoid arthritis, psoriatic arthritis, ankylosing spondylitis and other spondylarthritis) and gastrointestinal or liver comorbidity. Cochrane Database Syst Rev. 2012;1:CD008951.

14. Kellner HL, Li C, Essex MN. Efficacy and safety of celecoxib versus diclofenac and omeprazole in elderly arthritis patients: a subgroup analysis of the CONDOR trial. Curr Med Res Opin. 2012;28:1537-45.

15. Castellsague J, Riera-Guardia N, Calingaert B, Varas-Lorenzo C, Fourier-Reglat A, Nicotra F, Sturkenboom M, Perez-Gutthann S. On behalf of the investigators of the Safety of Non-Steroidal Anti-inflammatory Drugs (SOS) project. Individual NSAIDs and upper gastrointestinal complications. A systematic review and meta-analysis of observational studies (the SOS Project). Drug Saf. 2012;35(12):1127-46.

16. Ramirez-Alcantara $V$, LoGuidice A, Boelsterli UA. Protection from diclofenacinduced small intestinal. Toxicol Sci. 2010;118:276-85.

17. Wallace JL, McKnight W, Reuter BK, Vergnolle N. NSAID-induced gastric damage in rats: requirement for inhibition of both cyclooxygenase 1 and 2. Gastroenterology. 2000;119:706-14.

18. Wallace JL, Syer S, Denou E, de Palma G, Vong L, McKnight W, Jury J, Bolla M, Bercik P, Collins SM. Proton pump inhibitors exacerbate NSAID-induced small intestinal injury by inducing dysbiosis. Gastroenterology. 2011;141:1314-22.

19. Chan FK, Lanas A, Scheiman J, Berger MF, Nguyen H, Goldstein JL. Celecoxib versus omeprazole and diclofenac in patients with osteoarthritis and rheumatoid arthritis (CONDOR): a randomised trial. Lancet. 2010;376:173-9.

20. Antman EM, DeMets D, Loscalzo J. Cyclooxygenase inhibition and cardiovascular risk. Circulation. 2005;112:759-70.

21. Grosser T, Fries S, FitzGerald GA. Biological basis for the cardiovascular consequences of COX-2 inhibition: therapeutic challenges and opportunities. J Clin Invest. 2006;116:4-15.

22. Liu J-Y, Li N, Yang J, Li N, Qiu H, Ai D, Chiamvimonvat N, Zhu Y, Hammock $\mathrm{BD}$. Metabolic profiling of murine plasma reveals an unexpected biomarker in rofecoxib-mediated cardiovascular events. Proc Nat Acad Sci USA. 2010; 107:17017-22

23. Jacob JV. Nicorandil-induced colonic ulceration. BMJ Case Rep. 2015;2015: bcr2014205310.

24. Lewis S, Langman M, Laporte JR, Matthews JN, Rawlins MD, Wiholm BE. Dose-response relationships between individual nonaspirin nonsteroida anti-inflammatory drugs (NANSAIDs) and serious upper gastrointestinal bleeding: a meta-analysis based on individual patient data. Bri J Clin Pharmacol. 2002;54:320-6.
25. Sostres C, Gargallo CJ, Arroyo MT, Lanas A. Adverse effects of non-steroidal anti-inflammatory drugs (NSAIDs, aspirin and coxibs) on upper gastrointestinal tract. Best Pract Res Clin Gastroenterol. 2010;24:121-32.

26. Veeresham C. Natural products derived from plants as a source of drugs. J Adv Pharma Technol Res. 2012;3:200-1.

27. Soares-Bezerra RJ, Calheiros AS, da Silva Ferreira NC, da Silva FV, Alves LA. Natural products as a source for new anti-inflammatory and analgesic compounds through the inhibition of purinergic $\mathrm{P} 2 \mathrm{X}$ receptors. Pharmaceuticals. 2013;6:650-8.

28. Hefferon K. Plant-derived pharmaceuticals for the developing world. Biotechnol J. 2013:8:1193-202.

29. Newman DJ, Cragg GM. Natural products as sources of new drugs from 1981 to 2014. J Nat Prod. 2016;79:629-61.

30. Fürst R, Zündorf I. Plant-derived anti-inflammatory compounds: hopes and disappointments regarding the translation of preclinical knowledge into clinical progress. Mediat Inflamm. 2014;2014:146832.

31. Shah SM, Hussain F. Ethnomedicinal plant wealth of Mastuj valley, Hindukush range, District Chitral, Pakistan. J Med Plant Res. 2012;6: 4328-37.

32. Sharma PK, Sethi GS, Sharma SK, Sharma TK. Ethnomedicinal observations among the inhabitants of cold desert area of Himachal Pradesh. Indian J Tradit Knowl. 2006;5(3):358-61.

33. Hussain F, Shah SM, Sher H. Traditional source evaluation of some plants of Mastuj, District Chitral, Pakistan. Pak J Bot. 2007;39(2):339-54.

34. Singh KN. Traditional knowledge on ethnobotanical uses of plant biodiversity: a detailed study from the Indian Western Himalaya. Biodivers Res Conservat. 2012;28:63-77.

35. Mukerji KG, Manoharachary C. Current concepts in Botany. I.K. International Pvt Ltd. 2006;178.

36. Kumar S, Kashyap P. In-vivo anti-inflammatory activity of an methanolic extract of Fraxinus micrantha. ARC J Pharma Sci. 2015;1:1-4.

37. Iftikhar M, Riaz N, Saleem M, Tareen RB. Xanthoxyloidin, a new Biscoumarin from Fraxinus xanthoxyloides. J Chem Soc Pak. 2015;37:492-4.

38. Stefanova Z, Neychev H, Ivanovska N, Kostova I. Effect of a total extract from Fraxinus ornus stem bark and esculin on zymosan- and carrageenaninduced paw oedema in mice. J Ethnophamcol. 1995;46:101-6.

39. Lingadurai S, Nath LK, Kar PK, Besra SE, Joseph RV. Anti-inflammatory and anti-nociceptive activities of methanolic extract of the leaves of Fraxinus floribunda Wallich. Afr J Trad CAM. 2007;4:411-6.

40. Lingadurai S, Nath L, Kar PK, Vedasiromoni J: Anti-Inflammatory and antinociceptive activities of methanolic extract of the leaves of Fraxinus floribunda Wallich. Afr J Trad Comp Alter Med. 2007;4(4):411-416.

41. Organization for Economic Co-operation and Development. OECD guideline for testing chemicals 425. Acute oral toxicity-up and down procedure. 2001; 2:12-16.

42. Khan H, Saeed M, Gilani AH, Muhammad N, Haq I, Ashraf N, et al. Antipyretic and anticonvulsant activity of Polygonatum verticillatum: comparison of rhizomes and aerial parts. Phytother Res. 2013;27(3):468-71.

43. Muhammad N, Saeed M, Khan H. Antipyretic, analgesic and antiinflammatory activity of Viola betonicifolia whole plant. BMC Comp Alter Med. 2012;12(1):59.

44. Hoshino J, Park E-J, Kondratyuk TP, Marler L, Pezzuto JM, van Breemen RB, Mo S, Li Y, Cushman M. Selective synthesis and biological evaluation of sulfateconjugated resveratrol metabolites. J Med Chem. 2010;53(13):5033-43.

45. Park E-J, Kondratyuk TP, Morrell A, Kiselev E, Conda-Sheridan M, Cushman M, Ahn S, Choi Y, White JJ, van Breemen RB. Induction of retinoid $X$ receptor activity and consequent upregulation of p21WAF1/CIP1 by indenoisoquinolines in MCF7 cells. Can Prev Res. 2011;4(4):592-607.

46. You M, Wickramaratne DB, Silva GL, Chai H, Chagwedera TE, Farnsworth NR, et al. (-)-Roemerine, an aporphine alkaloid from Annona senegalensis that reverses the multidrug-resistance phenotype with cultured cells. J Nat Prod. 1995;58:598-604.

47. Ambethkar A, Ananthalakshmi S. GC-MS analysis on the methanolic extract of Trichosanthes anguina L. root. Int J Pharm Life Sci. 2014;5:3389-93.

48. Giugliano D, Ceriello A, Esposito K. The effects of diet on inflammation. Emphasis on the metabolic syndrome. J Am College Cardiol. 2006;48:677-85.

49. Afsar T, Khan MR, Razak S, Ullah S, Mirza B. Antipyretic, anti-inflammatory and analgesic activity of Acacia hydapica R. Parker and its phytochemical analysis. BMC Comp Alter Med. 2015;15:136.

50. Kang G-J, Kang N-J, Han S-C, Koo D-H, Kang H-K, Yoo B-S, Yoo E-S. The chloroform fraction of Carpinus tschonoskii leaves inhibits the 
production of inflammatory mediators in $\mathrm{HaCaT}$ keratinocytes and RAW264.7 macrophages. Toxicol Res. 2012;28(4):255-62.

51. Karin M. Nuclear factor-kB in cancer development and progression. Nature. 2006:441 (7092):431-6.

52. Kondratyuk TP, Pezzuto JM. Natural product polyphenols of relevance to human health. Pharmaceu Biol. 2004;42(S1):46-63.

53. Wang C, Schuller Levis GB, Lee EB, Levis WR, Lee DW, Kim BS, Park SY, Park E. Platycodin D and D3 isolated from the root of Platycodon grandiflorum modulate the production of nitric oxide and secretion of TNF-a in activated RAW 264.7 cells. Inter Immunopharmacol. 2004;4(8):1039-49.

54. Pitocco D, Zaccardi F, Stasio ED, Romitelli F, Santini SA, Zuppi C, Ghirlanda G. Oxidative stress, nitric oxide, and diabetes. Rev Diabet Stud. 2010;7:15-25.

55. Yang G, Lee K, Lee M, Ham I, Choi H-Y. Inhibition of lipopolysaccharideinduced nitric oxide and prostaglandin $\mathrm{E}_{2}$ production by chloroform fraction of Cudrania tricuspidata in RAW 264.7 macrophages. BMC Complment Altern Med. 2012;12:250.

56. Di Rosa M, Giroud JP, Willoughby DA. Studies on the mediators of the acute inflammatory response induced in rats in different sites by carrageenan and turpentine. J Pathol. 1971;104:15-29.

57. Winter CA, Risley EA, Nuss GW. Anti-inflammatory and antipyretic activities of indo-methacin, 1-(p-chlorobenzoyl)-5-methoxy-2-methyl-indole-3-acetic acid. J Pharmacol Exp Ther. 1963;141(3):369-76.

58. Liu YC, Zou XB, Chai YF, Yao YM. Macrophage polarization in inflammatory diseases. Int J Biol Sci. 2014;10:520-9.

59. Davidson S, Copits BA, Zhang J, Page G, Ghetti A, Gereauv RW. Human sensory neurons: membrane properties and sensitization by inflammatory mediators. Pain. 2014;155:1681-2.

60. Majid M, Khan MR, Shah NA, Haq IU, Farooq MA, Ullah S, Sharif A, Zahra Z Younis T, Sajid M. Studies on phytochemical, antioxidant, anti-inflammatory and analgesic activities of Euphorbia dracunculoides. BMC Comp Alter Med. 2015;15:349.

61. Cárdeno A, Aparicio-Soto M, la Paz SM-de, Bermudez B, Muriana FJG, Alarcón-de-la-Lastra C. Squalene targets pro- and anti-inflammatory mediators and pathways to modulate over-activation of neutrophils, monocytes and macrophages. J Func Food. 2015;14:779-90.

62. Lee JS, Ku SK, Lee SH, Jei Man Ryu JM. Composition for the prevention or treatment of allergic diseases comprising 2-linoleoyl glycerol. Google patent. 2012;WO 2012033348 A2.

63. Bradshaw HB, Walker JM. The expanding field of cannabimimetic and related lipid mediators. Br J Pharm. 2005;144:459-65.

64. Selloum L, Bouriche H, Tigrine C, Boudoukha C. Anti-inflammatory effect of rutin on rat paw oedema, and on neutrophils chemotaxis and degranulation. Exp Toxicol Pathol. 2003;54:313-8.

65. Guardia T, Rotelli AE, Juarez AO, Pelzer LE. Anti-inflammatory properties of plant flavonoids. Effects of rutin, quercetin and hesperidin on adjuvant arthritis in rat. II Farmaco. 2001;56:683-7.

66. Gao M, Ma Y, Liu D. Rutin suppresses palmitic acids-triggered inflammation in macrophages and blocks high fat diet-induced obesity and fatty liver in mice. Pharma Res. 2013;30:2940-50.

67. Huang M-T, Smart RC, Wong C-Q, Conney AH. Inhibitory effect of curcumin, chlorogenic acid, caffeic acid, and ferulic acid on tumor promotion in mouse skin by 12-0-tetradecanoylphorbol-13-acetate. Cancer Res. 1988;48:5941-6.

68. Chao P-C, Hsu C-C, Yin M-C. Anti-inflammatory and anti-coagulatory activities of caffeic acid and ellagic acid in cardiac tissue of diabetic mice. Nutr Met. 2009;6:33.

69. Shabbir M, Syed DN, Lall RK, Khan MR, Mukhtar H. Potent anti-proliferative, pro-apoptotic activity of the Maytenus royleanus extract against prostate cancer cells: evidence in in vitro and in vivo models. PLOS ONE. 2015:10: e0119859.

\section{Submit your next manuscript to BioMed Central and we will help you at every step:}

- We accept pre-submission inquiries

- Our selector tool helps you to find the most relevant journal

- We provide round the clock customer support

- Convenient online submission

- Thorough peer review

- Inclusion in PubMed and all major indexing services

- Maximum visibility for your research

Submit your manuscript at www.biomedcentral.com/submit

) Biomed Central 